\title{
LIVEABLE CITIES AND URBAN TRANSIT: LIVEABILITY IN A GLOBAL CONTEXT AND ITS CONNECTIONS TO THE GREATER TORONTO AND HAMILTON AREA (GTHA)
}

\author{
Daniele Alessio D'Alessandro \\ Honours Bachelor of Arts \\ University of Toronto, 2018
}

\begin{abstract}
A major research paper presented to Ryerson University in partial fulfillment of the requirements for the degree of

Master of Arts in the program of

Public Policy and Administration
\end{abstract}

Toronto, Ontario, Canada, 2019

(C) Daniele Alessio D'Alessandro, 2019 


\section{Author's Declaration}

I hereby declare that I am the sole author of this MRP. This is a true copy of the MRP, including any required final revisions.

I authorize Ryerson University to lend this MRP to other institutions or individuals for the purpose of scholarly research.

I further authorize Ryerson University to reproduce this MRP by photocopying or by other means, in total or in part, at the request of other institutions or individuals for the purpose of scholarly research. I understand that my MRP may be made electronically available to the public. 


\begin{abstract}
Liveable Cities and Urban Transit: Liveable Cities in a Global Context and its Connections to the Greater Toronto and Hamilton Area (GTHA)

Master of Arts in Public Policy and Administration (MPPA), 2019

Daniele Alessio D’Alessandro, Ryerson University

This MRP outlines the importance of transit in enhancing liveability. It does so by conducting a review of literature, identifying seven components of liveability (including transportation), and explaining how transit contributes to the individual components of liveability. Then, a jurisdictional scan of transit policies in Zurich, Vancouver, and Seoul was conducted to examine whether transit policies enhanced liveability in these cities. Finally, this MRP presented transit policy recommendations for the Greater Toronto and Hamilton Area (GTHA) and explained how improved transit would increase the GTHA's liveability. This MRP found that transit augments liveability in Zurich, Vancouver, and Seoul and that the contributions of transit to liveability are often overlooked by the literature and liveability indices. These findings show that transit should be viewed as an important variable that enhances liveability in cities.
\end{abstract}




\section{TABLE OF CONTENTS}

ABSTRACT .....................................................................................................................

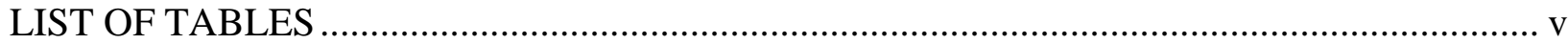

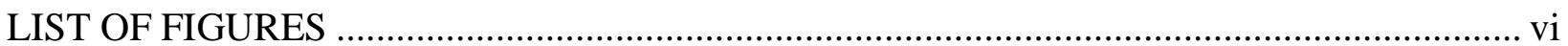

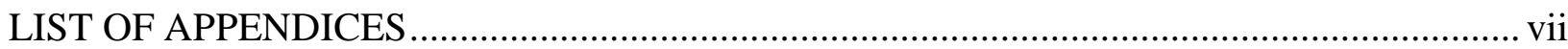

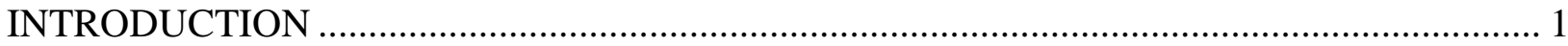

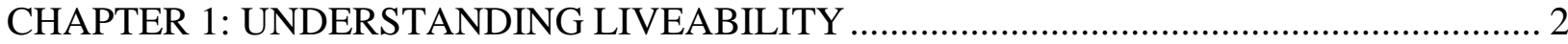

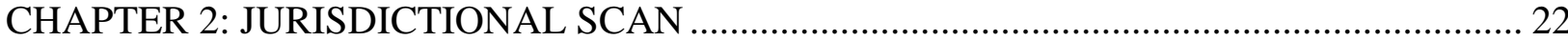

CHAPTER 3: THE GTHA AND LIVEABLE TORONTO ………………………………......... 33

CONCLUSION: UNDERSTANDING TRANSIT THROUGH A LIVEABILITY LENS .......... 48

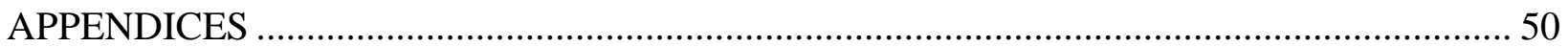

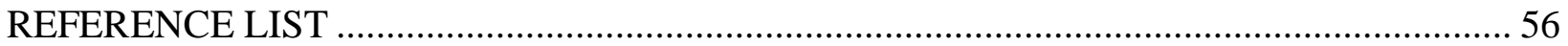




\section{LIST OF TABLES}

Table 1 - Adapted from OECD BLI (OECD BLI, n.d.a-k) ................................................... 53 


\section{LIST OF FIGURES}

Figure 1 - GTHA upper and lower-tier municipalities (Metrolinx, 2008a, p. 4) ....................... 34

Figure 2 - Future Transit Expansion Proposals for the GTHA (Draaisma \& Powers, 2019) ....... 41

Figure 3 - Toronto's Current Cycling Network (City of Toronto, 2017b) .............................. 46

Figure 4 - Proposed GTHA Regional Cycling Network (Metrolinx, 2018, p. 97) .................... 47

Figure 5 - EIU Liveability Rankings and Indicators (EIU, 2018, pp. 8-9) ............................... 51

Figure 6 - Mercer Quality of Living Ranking, Indicator Categories (Mercer, 2019) ................. 52

Figure 7 - European Green Capital Award's 12 Environmental Indicators (European Green

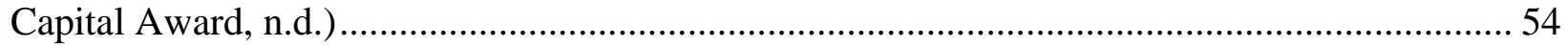

Figure 8 - Global City Indicators Program Categories and Indicators (Bhada \& Hoornweg, 2009,

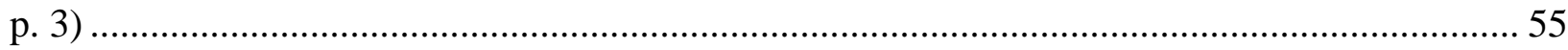




\section{LIST OF APPENDICES}

Appendix 1 - EIU Liveability Rankings and Indicators .................................................. 50

Appendix 2 - Mercer Quality of Living Ranking, Indicator Categories .................................. 52

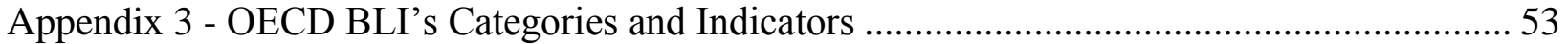

Appendix 4 - European Green Capital Award's 12 Environmental Indicators .......................... 54

Appendix 5 - Global City Indicators Program Categories and Indicators .................................. 55 


\section{INTRODUCTION}

An August 2018 CBC News headline read, "3 Canadian cities make top 10 on global ranking of most liveable cities (O’Neil, 2018, para. 1)." In the same week, similar news stories were posted on popular, far-reaching websites dedicated to all things Toronto, such as Daily Hive and BlogTO (Daily Hive Toronto, 2018). What these news stories have in common is that they compare cities and celebrate those at the top of the liveability scale. In fact, Jenny McArthur and Enora Robin found that news media coverage of urban liveability has skyrocketed in North America since the turn of the century to all-time highs in 2015 (McArthur \& Robin, 2019). Given the attention that liveability receives, it is worth asking what key characteristics make a city liveable.

This Major Research Paper (MRP) focuses on what liveability means, why it is important, and the implications for policy analysts and professionals. It begins by outlining the global challenges to liveability, and documents why liveability matters. It then discusses how different actors conceptualize liveability, given the lack of a standard definition, and outlines the benefits of liveability for policy analysts, governments, residents, and communities. After providing an overview of the main features of liveability, this MRP turns to emphasize transit as an important feature that can potentially enhance and compliment the other components of liveability by examining transit policy case studies in Zurich, Switzerland, Vancouver, Canada, and Seoul, South Korea. Finally, it turns to discuss how Toronto, Canada can increase its liveability by improving its transit system. This MRP argues that despite its high ranking on several liveability indices, Toronto and the Greater Toronto and Hamilton Area's high liveability status nevertheless falls short when looking specifically at its transit system. 


\section{CHAPTER 1: UNDERSTANDING LIVEABILITY WHY FOCUS ON LIVEABILITY?}

Over the course of the twentieth and twenty-first centuries, the world has experienced exponential rates of urbanization, creating new challenges for cities. As of 2018, 55\% of the world's population lives in an urban area and that number is expected to increase to $68 \%$ by 2050. According to the United Nations, currently, 1 in 8 people live in 33 megacities that contain over 10 million people (United Nations [UN], 2018). The increasing rates of urbanization and the rise of megacities present several challenges including inequality, sprawl, congestion, and pollution. The concept of liveability seeks to inform policymakers as to how to address these challenges to enable people to live with a high quality of life in increasingly dense urban settings.

As cities become denser and expand outwards, they can create issues for local governments. The expansion required to accommodate large numbers of people can result in economic inequality within cities and surrounding suburbs. For example, David Hulchanski argues that income rates in Toronto vary widely between the city's downtown core and suburbs. Certain suburbs have significantly lower incomes than the city's core, to the point where Toronto neighbourhoods resemble three different cities (2007). The growth of Toronto, since the 1970s, together with the rising cost of housing in the city core, have pushed people with lower incomes to the suburbs, where the distribution of lower incomes has increased significantly from 1970 to 2005 (Hulchanski, 2007). The trend that Hulchanski identifies in Toronto occurs elsewhere as well. In the United States, greater numbers of low-income Americans live in suburbs than in the centre of large cities (Badger, 2013). While there are still many wealthy suburban communities in North America, the trend is that increasing density in downtown cores is raising property 
values and rental costs, making housing in downtown cores unaffordable for low-income residents. However, moving to the suburbs is not without costs since individuals and families must then consider increased demand, and hence, housing costs even in the suburbs, increased commuting costs associated with purchasing and maintaining vehicles, and potentially, higher taxes as municipalities build the infrastructure necessary to serve once empty lands (Diamond \& Thompson, 2018). Urbanization and the rise of megacities have increased inequality within cities.

The negative impact of density and urbanization extends beyond economic issues. When suburbia expands, rates of congestion increase because residents need to commute longer distances to get to work and to access services. According to a Statistics Canada study, 1.5 million people in Canada spent an hour or more commuting to work in 2016 and $57 \%$ of them did so by car (Bennardo, 2019). Statistics Canada also reports that in some suburban cities near Toronto, such as Barrie and Oshawa, nearly $20 \%$ of residents commuted an hour or more to work (2019). Many transit users (30\% in 2016) especially where transit is inadequate (Bennardo, 2019) also spent an hour or more to get to work. Aside from lost time and money, long commutes can have detrimental impacts on people's health by increasing stress and decreasing the time devoted to personal care and relationships. Long commutes fill already congested roads and highways, furthering air pollution in cities, which according to the World Health Organization, has worsened in recent years (n.d.a) while exacerbating the effects of climate change.

Climate change is a global problem that is having a disproportionate impact on cities. According to a UN Environment Program, cities generate an estimated $75 \%$ of the world's carbon dioxide emissions (n.d.) and will suffer the most serious damages as the earth warms. 
Cities and the $90 \%$ of the world's urban population living near the coastal regions can expect to withstand the worst of powerful storms, heatwaves, flooding, and rising sea levels (UN Habitat, n.d.).

What role does the concept of "liveability" play against such global challenges? This MRP does not argue that liveability will be the solution that saves the world from all its challenges. Rather, it suggests that the concept can help focus policymakers toward achieving key outcomes that will be important for addressing today's urgent challenges (Okulicz-Kozaryn, 2013). Since liveability sets a series of objective standards, as Okulicz-Kozaryn argues, it is a useful tool to focus global responses to global issues. Cities can work to address policy issues by improving their performance against liveability indicators through the adoption of policies appropriate for each jurisdiction. For example, the Economist Intelligence Unit (EIU) measures the quality of public transport as one indicator of liveability (2018). Thus, cities striving to be liveable would also wish to improve transit. Liveability, as a concept, identifies key principles and the job of policymakers is to offer the means to realize those principles.

\section{REVIEW OF LITERATURE: VARYING DEFINITIONS OF LIVEABILITY}

While the concept of liveability is recognized globally, there is no standard definition.

Understandings of liveability vary depending on who uses the term. Liveability is popular among governments, specifically municipalities, consultancy firms, international organizations such as the OECD, the World Bank, and academics. The World Health Organization defines a liveable city as a healthy one that helps residents achieve a good quality of life by forging connections in the political, economic, and social arenas (n.d.b). With this in mind, it is worth noting how these actors vary in their understanding and use of the concept. 


\section{Municipal Governments}

Many municipalities around the world pay attention to the concept of liveability with the City of Toronto as a prominent Canadian example. In the second chapter of its Official Plan, the City of Toronto indicates several principles aimed at "building a more liveable urban region" (2015, chap. 2, pp. 1-3). This section of the official plan outlines how Toronto will work with the Province of Ontario and neighbouring municipalities to create a liveable Greater Toronto and Hamilton Area (GTHA) region. Toronto is leading efforts to promote liveability in the GTHA because it sees itself as the economic centre of the GTA, and advocates regional policy approaches to transportation and the environment, affordable housing, and a vibrant hub for healthcare, education, culture, and entertainment (City of Toronto, 2015). Toronto is a municipality that is responsible for contributing to and enhancing the quality of life for its residents not only within its borders but also within the entire GTHA. As McArthur and Robin note, municipal governments around the world use the concept of liveability to frame policy proposals in an appealing and innovative way, and to demonstrate that the municipality - and not another order of government - is taking concrete policy action (2019). Similarly, the City of Toronto's official plan's description of its role in the GTHA urban region largely follows the same pattern of using a liveability discourse to demonstrate its leadership, and to justify its policies to the public.

\section{Consultancy Firms and Liveability Rankings}

In contrast to municipal governments, consultancy firms focus on international comparisons among cities, using qualitative and quantitative indicators to rank factors that affect the quality of 
life in cities. Common factors include the environment, education, the economy, safety, affordability, and entertainment. Two significant liveability rankings are the Economist Intelligence Unit's Global Liveability Index and the Mercer Quality of Living Survey. The EIU's liveability ranking has 40 indicators of liveability under five categories: stability, healthcare, culture, environment, and education (Kashef, 2015) (see Appendix 1). The EIU focuses on comparing the most and least liveable cities, the factors that make cities liveable, and movements in the rankings over time. The Mercer Quality of Living Survey compares 460 cities against 39 indicators under the following categories: sociopolitical environment, economics, sociocultural environment, health, education, utilities, recreational facilities, housing, and natural environment (Kashef, 2015) (see Appendix 2). The Mercer Quality of Living Survey allows for an in-depth comparison of life in multiple cities. Mercer also offers over 140 location-specific reports that assess quality of life in cities on its website. Mercer approaches liveability rankings from a business perspective, and views them as valuable tools for companies in the private sector to decide where to invest, or to relocate and move employees internationally (Kashef, 2015). Of course, politicians and the public sector can use the influx of business and a boost in the economy to validate their accomplishments.

\section{International Organizations}

Several international organizations also use liveability rankings to compare life among countries. For example, the Organization of Economic Cooperation and Development (OECD) has a Better Life Index (BLI) that compares the quality of life across nations using data from the United Nations and Gallup (Kashef, 2015). The OECD BLI evaluates cities based on 24 indicators in the categories of housing, income, jobs, community, education, environment, civic engagement, 
health, life satisfaction, safety, and work-life balance (n.d.a) (see Appendix 3). The European Commission's European Green Capital Award focuses on the environment as an important liveability indicator, and grants the award to one European city annually based on how it performs against 12 measures primarily related to climate change, sustainability, the physical environment, and governance (n.d.) (see Appendix 4). The World Bank, in partnership with the Global City Indicators Facility at the University of Toronto, has also created the Global City Indicators Program (GCIP), where officials from different cities can report on a common set of indicators digitally. The GCIP consists of 18 indicators divided in two categories: city services

and quality of life (Bhada \& Hoornweg, 2009) (see Appendix 5). The International Organisation for Standardization (ISO) also recognizes the GCIP (n.d.). Several international organizations use liveability indicators to rank cities against one another. The adoption of city-benchmarking shows that liveability indicators can be useful for global comparisons.

\section{Discipline-Specific Definitions}

Liveability also remains a popular concept within several distinct disciplines. Here too, since the term tends to be adapted to the field in which it is used, there is a lack of consensus as to what liveability specifically means. For example, urban design/urban planners use liveability to create conceptions of the ideal city (Kashef, 2015; Miller et al., 2013). In contrast, environmentalists understand liveability from a conservation and ecological perspective, as exemplified by the previously mentioned European Green Capital Award. Ruggeri, Harvey, and Bosselmann find that environmental audits assist in affirming an environmental approach to liveability in the field of urban design (2018). To give another example, architects understand liveability in relation to “density, morphology and building performance" while urban planners highlight land use as a 
component of liveability and, landscape architects analyze liveability based on the availability of user-friendly public spaces (Ruggeri et al., 2018, p. 251). Policy analysts and political scientists use indicators to compare outcomes, and to justify policy options (Miller et al., 2013). Miller et al. point out that transportation planners have also incorporated ideas of liveability and sustainability in their work to show how transit can support and enhance sustainable cities (2013). Despite the wide-ranging and varying uses of the concept, various disciplines and professions use the term "liveability" generally to connote positive and vibrant public spaces.

\section{Liveability Indicators in Industry}

Liveability indicators add to the existing practice of using key performance indicators, which is common in both the private and public sector. Indicators serve not only to measure outcomes but also to identify shortcomings and hence, to define needs. From a policy perspective, liveability indicators can aid in problem identification and in assessing outcomes. They are also useful for policy analysts, consultants, and governments precisely because they enable comparisons across cities, which in turn allows governments to assess their current performance against those in other jurisdictions (Lowe et al., 2015). Comparison against a common benchmark, goal or set of criteria can help shape the policy foci of government departments. Furthermore, liveability indicators then become the basis for monitoring policies, and measuring policy outcomes against set criteria over time (Lowe et al., 2015). Leach, Lee, Hunt, and Rogers note that while comparisons can be made among actors using the same set of indicators, liveability indicators are often designed to fit the needs of a specific organization, making comparisons somewhat difficult (2017). As such, the highest quality indicators that have the potential to make deep impacts are those that one can apply across multiple contexts (Leach et al., 2017). In many respects, 
organizations such as Mercer and the Economist Intelligence Unit have addressed the concerns of Leach et al. by creating indicators that can be applied globally. Liveability indicators remain popular because of their ability to both identify issues and measure progress in the public sector.

\section{Liveability Indicators for Other Levels of Government}

Other levels of governments may also use liveability indicators to set their own agenda. Due to the lack of a central, agreed upon definition of liveability, governments have generally defined the term to suit their purposes and to measure progress toward the goals they set. For example, Balsas points out that a government can identify variables it will use to address a problem, focus on the specific policy responses to address the relevant issue(s), create indicators, and evaluate their own performance against those indicators (2004). Governments are then free to tie those indicators to concepts such as liveability. While the obvious concern is that governments may adjust the definition of success to meet their particular policy outcomes, scholars such as Tomalin note that globally recognized core indicators should complement context-specific indicators to ensure credible comparisons (Balsas, 2004). Finally, there is not always a reliable, consistent method used to measure policy outcomes in the public sector. For instance, it may be easy to measure decreases in $\mathrm{CO} 2$ emissions associated with decreases in vehicle use. However, Natural Resources Canada (2016) points out that if motorists reduced their daily idle time, a condition of being stuck in traffic, by three minutes, $\mathrm{CO} 2$ emissions would decrease by 1.4 million tonnes a year with no decrease in car use. Similarly, the American Department of Transportation found that per mile $\mathrm{CO} 2$ emissions from transit, regardless of mode, is $50 \%$ lower than private vehicle use (Hodges, 2010). It is even more difficult to measure the health benefits of using public transit or the impact of open public spaces on "quality of life" (Lowe et al., 2015, 
p. 139). Liveability indicators, specifically those created by governments, think tanks, consultants, and third sector organizations can possibly help quantity new or abstract concepts that have no agreed upon core indicators or that the private sector ignores.

\section{Shortcomings of Liveability Indicators}

There are of course weaknesses in using liveability indicators. A primary concern is that currently there is little consensus on an agreed upon set of indicators or how to measure "success." As Leach et al. argue, since there is no single method to creating indicators, the selection of certain criteria may be biased, arbitrary, or vary in rigour. In addition, setting thresholds for success and failure is a difficult process that, when done by governments, should be (but often may not be) transparent, and include frameworks outlining how to leverage data for indicators (2017). Creating and maintaining indicators requires significant resources. Local governments (the level of government that most often uses liveability indicators) must hire sufficient staff to develop indicators, gather documents, monitor conditions, collect, and analyze the data, but may have limited resources to devote to such policy work. The alternative is using consultants to create indicators or to compile agreed upon indicators from existing indices, which also poses challenges. Consultants are expensive, and their indicators may not yield information of value because they may not understand the current issues facing any particular local government (Lowe et al., 2015; McArthur \& Robin, 2019). Existing indices may not reflect a city's needs or demographic groups, resulting in unrealistic indicators that may also be class biased (McArthur \& Robin, 2019). In addition to the challenges posed by the creation and maintenance of indicators, general liveability indices are aggregate measures that can mask performance in specific areas. In looking at an overall measure of liveability, it is important to 
disaggregate composite measures to determine what aspects are missing. Finally, there is an assumption that different measures of liveability are relatively equal in significance to all cities. Assuming so ignores the fact that some indicators may be more meaningful to some cities rather than other cities (Lowe et al., 2014). These shortcomings have led to criticism of the cities presented in various liveability rankings.

Given this MRP's focus on transit, it is important to note the issues regarding how transit fits into liveability indices. First, Mercer does not release the metrics used to evaluate liveability, making it difficult to assess the extent to which transit is a feature of liveability. Second, in the EIU's rankings, transit is aggregated in the infrastructure category (worth $20 \%$ of a city's ranking) alongside seven other metrics including quality of road network; public transport; international links; energy provision; water provision; telecommunications; and the availability of good quality housing (EIU, 2018). Several other metrics tend to incorporate public transit into other indicators, which can mask serious shortcomings in transit. In the GTHA's context, the region's sophisticated road network, energy grid, water and wastewater system, and telecommunications infrastructure tend to eclipse transit, thereby masking transit deficiencies. In this respect, liveability indices may not accurately reflect the importance of a transit system to liveability in a city-region.

\section{Leaders in Liveability in Recent Years}

Between 2014 and 2018, several cities consistently ranked in the top ten most liveable cities in both Mercer's Quality of Life Index and the EIU's Global Liveability Ranking. While there are many organizations that produce liveability rankings, Mercer and the EIU's rankings were chosen for this analysis because both rankings are recognized as being the most comprehensive 
and they are frequently referenced throughout the literature. Vienna, Vancouver, and Auckland were ranked in the top ten most liveable cities for five subsequent, annual rankings from 2014 to 2018, with the exception of Auckland in the EIU's 2014 and 2018 rankings. In each liveability index, several cities appear frequently with some minor variations over the years. (EIU, 2014; EIU, 2015; EIU, 2016; EIU, 2017; EIU, 2018; Siscovick, 2014; Nairn, 2015; Andersen \& Reilly, 2016; Andersen, Reilly, \& Siscovick 2017; Andersen, Tournier, \& Siscovick, 2018). However, the same cities often ranked in the top ten for multiple years on the Mercer's and the EIU's rankings. The repeat appearance of cities ranked as the most liveable suggests that the criteria to evaluate liveability is fairly consistent, and that making improvements in liveability rankings is a task that can take a city a number of years to accomplish.

\section{The Components of Liveability}

At this point, it is important to step back to identify the diverse characteristics that make a city liveable. Liveability, while lacking a firm definition, nevertheless shares many common elements. In a comparison of six liveability indices, McArthur and Robin (2019) identify seven key components, which this MRP adopts. They include:

- safety and political stability, that is, freedom from violent crime, government corruption, and the negation of human rights;

- available public services such as healthcare, education, and public infrastructure including electricity, water and wastewater provision, waste collection, and telecommunications;

- a flourishing economy;

- clean environments and accessible greenspaces; 
- culture and recreation through public institutions and public spaces;

- social cohesion expressed by a sense of community, economic solidarity, and civic participation; and,

- safe, clean, and effective ways to get around the city for all ages, including pedestrian walkways, bike paths, and an efficient, integrated, affordable, regional transit system.

The next section will expand on these components and their position in the literature and liveability rankings.

\section{Safety and Political Stability}

Liveable cities provide stability and security that enable residents to enjoy the benefits from the natural or built environment, and not worry about corruption, terrorism, political instability, military conflict, social unrest, or widespread crime (McArthur \& Robin, 2019; EIU, 2018). The OECD measures safety using the homicide rate and the percentage of the population that feels safe walking alone at night (OECD BLI, n.d.b). Safety and political stability first assume that liveable cities must not be facing war, tyrannical and authoritarian governments, or consistent threats of terror. Secondly, crime rates for both violent and minor crime need to be sufficiently low so people feel safe to engage in activities in their everyday lives.

\section{Public Services}

Liveable cities provide accessible and quality public services that address the needs of their residents. Public services include healthcare, education (McArthur, 2009), and critical infrastructure such as electricity, water and wastewater provision, waste collection and telecommunications infrastructure (EIU, 2018). While healthcare, education, and infrastructure 
institutions can vary widely across jurisdictions, the quality and availability of these services determine a city's liveability. The BLI measures health by life expectancy (OECD BLI, n.d.c) and the EIU measures both quality and availability of public and private healthcare as well as general indicators of health from the World Bank (EIU, 2018). The liveability indices reveal that having predictable and stable access to high-quality healthcare, regardless of the format of the healthcare system, makes a city liveable.

The outcomes regarding education are similar. The BLI measures education by years of education with higher levels of educational attainment as an indicator of liveability (OECD BLI, n.d.d). Like its approach to healthcare, the EIU measures the quality and availability of private education as well as World Bank indicators regarding the quality and availability of public education (EIU, 2018). The BLI implies that liveable cities generally have well-educated residents, whereas the EIU focuses on access to quality education.

As for infrastructure, the BLI does not include this measure in its concept of a liveable city. However, the EIU notes that the quality of infrastructure particularly related to utilities (water, hydro, telecom) is critical to a city's health (EIU, 2018). Quality road networks, transit systems providing effective movement throughout the city, and pedestrian/cyclist pathways also add to the overall quality of life. Infrastructure needs to be both resilient, that is, the ability to recover from events such as natural disasters, and reliable, operate effectively, and provide service to all residents (Reiner and Rouse, 2018).

\section{Economy}

A healthy economy welcomes both public and private investment that can sustain the critical public services offered in liveable cities. Economies are essential components of any society but 
it is worth noting that there is no definition of a "liveable economy." In fact, there is very little in the way of academic literature on what the economy in a liveable city should look like. By all accounts, the BLI provides the most comprehensive understanding of the economic factors that contribute to a high quality of life. Liveability considers core economic indicators such as income and jobs to assess quality of life. For example, the BLI analyzes household financial income and household net disposable income to assess overall incomes (OECD BLI, n.d.e). The BLI also considers factors such as job security, earnings, long-term unemployment rate, and the employment rate when assessing jobs as a component of liveability (OECD BLI, n.d.f). These income themed indicators suggest that liveable cities have economies that provide stable employment for residents. By extension, liveable cities should also be attractive places for the private sector to grow, invest, and to provide high-paying, stable jobs to communities. To assess the economies of liveable cities, the Mercer Quality of Life Index measures liveability by analyzing access to consumer goods, housing, and an efficient transit system that can transport people safely and reliably (2019). Other economic measures that can be incorporated into liveability include the human development index, Gini coefficients, ecological footprint (Miller et al., 2013), GDP, and GDP per capita.

Liveability importantly also focuses on housing affordability, and economic equality. Affordable housing, indeed, affordability generally and economic equality are key indicators of liveable cities. Nonetheless, the BLI considers housing expenditures, measured by the ratio of disposable income to housing costs (OECD BLI, n.d.g) as an indicator of housing costs. When residents spend an average of $21 \%$ of disposable income on housing across the OECD, housing becomes a critical expense for many (OECD BLI, n.d.g). Economies in liveable cities must be sufficiently strong to provide salaries that can support rental or homeownership expenses. As 
well, liveable cities need to prioritize building a stock of affordable housing. A long commute may be a disincentive for future employers and employees to move to a city despite a good transit system.

\section{Environment and Greenspaces}

The environment and greenspaces are critical components of liveability, due to their ability to mitigate pollution, provide ecosystem services (discussed below), and recreational benefits. In liveable cities, features of the natural environment support life. The BLI indicator on the environment measures water and air pollution levels, with high pollution rates negatively affecting the quality of life (OECD BLI, n.d.h). Overall cleanliness and reduced pollution make cities liveable and these become a source of pride for residents (Tapsuwan, Mathot, Walker, \& Barnett, 2018; Leyden, Goldberg, \& Duval, 2001). A factor that assists in reducing overall pollution in cities, particularly from vehicles, is an extensive, convenient, and well-functioning transit system that takes cars off the road, while promoting green or sustainable methods of transportation. Beyond having clean water, and air, greenspace also provides third spaces, that is, spaces that are not home or work, which can enhance civic life by bringing people together to enjoy leisure time (Leyden et al., 2001). Here, the natural environment becomes important for cities. Alongside efforts to keep the natural environmental features such as lakes, rivers, fields, and forests clean and healthy, cityscapes should actively focus on incorporating greenspace. While parks provide numerous benefits since they operate as ecofriendly third spaces, green solutions do not stop at greenspaces. Urban vegetation such as community gardens, native plants, trees, shrubs planted along street corridors, sidewalks, and pathways provide numerous, valuable ecosystem services that reduce pollution and support cities. Good examples of ecosystem 
services include trees and vegetation that serve to collect carbon, reduce noise and air pollution, increase food supply, assist in stormwater management, and mitigate flooding risks (Säumel, Weber, \& Kowarik, 2016). A city's road network can incorporate trees and vegetation to beautify cities and improve the health of residents and the environment. These ecosystem services can help reduce pollution, mitigate climate change, and reduce damage from natural disasters. Beyond these health and aesthetic benefits, greenspaces can boost tourism, create educational opportunities, enhance culture, and increase property values (Säumel et al., 2016). These services create tangible benefits for communities and make cities attractive destinations in which to live, work, and play.

\section{Culture and Recreation}

In addition to providing greenspace for leisure, liveable cities provide venues for a diversity of recreational and cultural activities. Cultural facilities come in several forms including traditional venues such as museums, art galleries, concert halls, and modern forms such as space supporting graffiti, street art, pop-up displays, street food, as well as restaurants and bars, sport-viewing squares, and in some cases, piazzas where they did not previously exist. While attracting tourists may be one factor motivating cities to enhance recreational and cultural activities, the literature notes that such recreational and cultural features do much to help promote a healthy work-life balance (Leyden et al., 2001; Nofre, Giordano, Eldridge, Martins, \& Sequera, 2018). The OECD BLI recognizes that having a work-life balance is a key component of liveability and measures it by the amount of time devoted to personal care/leisure and the percentage of the population working long hours, defined as over 50 hours a week (OECD BLI, n.d.i). The EIU considers opportunities for leisure and a work-life balance in its liveability index as it assesses the 
availability of culture and sport, alongside food and drink (EIU, 2018). Of course, an affordable, reliable, comprehensive and accessible transit system can play a key role to ensure that residents and visitors are able to reach various cultural, entertainment, and sport venues (Nofre et al., 2018).

\section{Social Cohesion}

Liveability cannot be limited to a discussion of physical places. Rather, the dynamics at play among residents in these spaces can potentially affect quality of life. McArthur and Robin point out that liveability indices stress the importance of factors such as tolerance and equity in cities (2019). According to McArthur and Robin, tolerance refers to the relations among groups, while equity emphasizes both social equality and economic equality. Liveable cities are spaces where different demographic groups in cities, differentiated by factors such as income, race, religion, ethnicity, gender, and sexual orientation are not segregated from one another. For example, Smets argues that an ideal liveable city is one where the rich and poor are integrated into one community both physically and economically, where those who are financially privileged will support those who are less financially well off through jobs and local businesses (Smets, 2005). The way cities address the needs of economically marginalized populations is critical to liveability. For example, Holden and Scerri note that liveable cities address issues such as homelessness by providing measures to alleviate poverty and the stigma associated with poverty (2012). Liveable cities should seek to reduce the "us versus them" (Smets, 2005) concept that exists in some communities where powerful groups work to protect their status from others that they perceive as outsiders. Many cities that may score high on the liveability scale in other dimensions but may fall short on this measure, given that most large metropolitan areas tend to 
have well-defined neighborhoods divided by class, race, religion, and ethnicity. Rather than the idealized version of "one big happy unified city," social cohesion and having a sense of community as measures of quality of life can mean the existence of spatially defined communities that nonetheless manage to live harmoniously, side-by-side. For example, researchers often measure a sense of community by the percentage of people who feel they can rely on their friends in times of need (OECD BLI, n.d.j; OECD BLI, n.d.k). In cities with multiple ethnic and religious enclaves, residents may have many people to whom they can look for help within their own community as opposed to the city at large. Not connecting with people outside a particular cultural, ethnic, or religious community may not diminish a person's sense of social cohesion.

Civic engagement is another component of the social environment worth outlining. Smets notes that social cohesion exists through formal and informal soft infrastructure, which increases communal bonds. Formal infrastructure refers to various organizations such as charitable groups and sports leagues, while informal bonds refer to individual connections and community groups that provide social cohesion in a city (Smets, 2005). Thus, civic engagement in liveable cities includes access to non-traditional forms of political participation such as interest or community groups, although traditional forms of civic participation, such as voting is still important for overall social cohesion. The BLI measures civic engagement through voter turnout, stakeholder engagement in policymaking, which should include young and older people, and notes that civic engagement increases quality of life (OECD BLI, n.d.k).

\section{Transportation}


Transit systems in liveable cities move away from vehicle dominated spaces and car dependency toward streets that support other forms of transportation such as light rail, cycling, and walking (Biddulph, 2012). Streets, including arterial roads, with reduced levels of traffic, and lower speed limits will invite residents to walk around and enjoy city amenities. Roads that feed vehicles onto arterial routes and create "heavy" streets are not encouraged. Rather, for liveable cities, streets should carry under 3000 cars a day (Marshall \& McAndrews, 2017). Liveable streets emphasize adopting surface or light rail transit that are safe for pedestrians, cyclists, and motorists. Light rail, if planned well, can lead to the rejuvenation and transformation of streets once dominated by vehicles to create spaces that are vibrant and interconnected. Bus rapid transit is an acceptable alternative for smaller cities and routes (Ferbrache \& Knowles, 2017). For example, light rail or bus rapid transit combined with on-street parking, can encourage pedestrians to walk and enjoy retail shops, restaurants, bars, parks on an arterial road. In fact, the addition of transit can increase walkability and cycling in dense areas such as city centers that provide commercial, leisure, residential, and office space (Hooper, Knuiman, Foster, \& Giles-Corti, 2015). In the literature, there is a recognition that light rail can only go so far in terms of moving people. Kenworthy notes that regional rail, like Ontario's GO Transit, is an effective method for moving people from the peripheries into the core of cities (2006). There, people can then use other forms of transportation such as subways, light-rail routes, cycling, or walking to reach their destination. Kenworthy notes that large parking lots should not dominate the city centre. Rather, residents can navigate the city through transit (2006). Liveable cities promote walkability with access to reliable transit whether in the form of light-rail or bus when residents need to travel further.

A move toward public transit use and away from vehicle use has several health, safety, and environmental benefits. Creating streets that emphasize walking and transit use promotes 
safety, and decreases the risk of pedestrian and cyclists' accidents with vehicles (Geller, 2003). From a health perspective, transit systems encourage "active living," which can decrease the incidences of obesity (Geller, 2003). From an environmental perspective, decreasing vehicle use will reduce smog, GHG emissions, and air pollution. Creating streets that promote walkability can also result in renewed interests among residents in greenspaces, especially if connected to arterial roads through pedestrian access points (Hooper et al., 2015). Similarly, promoting light rail transit or buses over vehicles can reduce overall pollution rates, with underground light rail tracks or green tracks (Ferbrache \& Knowles, 2017). Improving transit can help make access to employment more possible for a greater number of people and help reduce traffic congestion. Transit also enables companies to find the right employee for the job due to faster commuter times; reduces overall congestion (Badland et al., 2015; Amar \& Tucklucksingh, 2015); attracts companies to cities (Ferbrache \& Knowles, 2017); create jobs in the construction of transit, and stimulate local businesses, due to increased pedestrian activity. Creating liveable streets also supports the components of liveability such as culture and recreation, and social cohesion. Ferbrache and Knowles point out that transit can become a source of pride for a city by promoting connections among residents. Transit can also be adapted to the area it is placed and transit stations/stops can include the installation of public art, incorporation into the existing architectural patterns in the area, and transit routes can symbolize modernity and progress (2017). In addition, transit generally supports the recreational and cultural centres of cities by filling them with residents ready to enjoy what the spaces have to offer. A good transit system is arguably an important component of liveability because it potentially sustains the other elements by promoting the safety, health, environment, and economy of cities while strengthening the cultural and social ambiance of communities. 


\section{CHAPTER 2: JURISDICTIONAL SCAN}

This section conducts a jurisdictional scan of three top cities that rank high on liveability and examines the role of transit policy in supporting liveability. The chapter begins by outlining the rationale for selecting the case studies, and then briefly outlines the historical development and rationale for their transit policies, since one cannot assume that liveability is the sole or even primary driver for transportation policies. The findings from this chapter will be useful in informing the following chapter that will discuss the Greater Toronto and Hamilton Area.

\section{WHY ZURICH, VANCOUVER, AND SEOUL?}

Zurich and Vancouver have a number of similarities that make them good case studies to analyze whether, and how, transit policy contributes to liveability. First, Zurich and Vancouver rank highly on several liveability indices. Zurich placed second while Vancouver placed third on Mercer's Quality of Living Rankings in 2019 (Mercer, 2019). Similarly, Zurich placed eleventh on the EIU's 2018 Global Liveability Index, missing the tenth spot by just 0.03 points, whereas Vancouver ranked sixth (Swissinfo, 2018). The question is this: what role does transit policy play in making these two cities liveable?

The selection of Seoul may appear controversial due to its low placement on both the Mercer and the EIU liveability rankings. Recall however that rankings are aggregate figures, and Seoul's relatively low standing could reflect the security risks it faces from its North Korean neighbour. Nonetheless, Seoul does score well on a number of other scales such as 
PriceWaterhouseCoopers and Partnership for New York City's Cities of Opportunities index, where Seoul ranked eleventh in 2016 (Seoul Metropolitan Government [SMG], n.d.)

It is also important to review the limitations of these cases. The cities that rank highly on liveability rankings tend to be small or midsized in population and wealthy. As McArthur and Robin point out, the liveability metrics of the most common liveability rankings, including the EIU and Mercer, reflect the interests of the highly educated, urban-dwellers, and those who participate in the city experience, rather than in a suburban, rural, or traditional lifestyle. Notably, this bias excludes the many cities characterized by inequality, in favour of more economically homogenous cities (2019). Thus, smaller and wealthier cities stand at the top of liveability rankings. For example, the most populous city on Mercer's top ten is Vienna and Auckland is the only city outside Europe on the list (Mercer, 2019). The EIU's rankings are more favourable to cities with higher populations such as Tokyo, Melbourne, Sydney, and Toronto, all of which placed in the top ten (EIU, 2018). However, no American city or megacity appears on these lists suggesting that wealthy, medium-sized cities in developed nations may be a necessary but not sufficient condition for liveability. For this reason, it is important to keep in mind that liveability recommendations may not be applicable for all urban settings.

\section{ZURICH}

\section{City Profile}

The City of Zurich is the capital of its Canton, Zurich. The city is home to 380,500 people in its immediate core and 1.9 million in the Zurich Metropolitan Area (ZMA) (Stadt Zurich, 2013). About $26 \%$ of Zurich's residents live in the city's core, while the rest live in surrounding suburbs. Despite the small population relative to other European cities, Zurich has a high population density. Within its city centre, Zurich's population density was 4,432 people per $\mathrm{km}^{2}$ 
in 2015 and its suburban density was 651 people per $\mathrm{km}^{2}$ in 2015 . These figures are higher than several other large European cities such as Hamburg, Vienna, and Berlin (Buehler et al., 2019).

\section{Historical State of Zurich's Transit System}

Prior to the 1980s, public debate over what modes of mass transit the city should adopt shaped Zurich's transit system. The City of Zurich had a public tram system since 1894 (Mees, 2010) with an extensive road network complementing the tram system by connecting different cities in the country to the Canton (Tschoop \& Axhausen, 2008). The Zurich Metropolitan Area (ZMA) maintains a heavy passenger rail system, called the Gold Coast Express, which began operation in 1968 (Mees, 2010). Despite having a tram, road, and train network, each component served different parts of the ZMA, creating a poorly integrated transit system as exemplified by a sophisticated tram system in Zurich City that did not link to surrounding suburbs. As well, Zurich's neighbouring municipalities had autonomous transit systems rather than one regional system, and infrequent rail and bus service in rural communities (Mees, 2010). The lack of effective connections among the ZMA's cities promoted vehicle dependency, as the number of automobile owners per 1000 people tripled from 1960 to 1980 (Buehler, Pucher, \& Dümmler, 2019). The increase in traffic and congestion sparked called for improving public transit. The People's Initiative for Public Transport, a pro-transit initiative proposed to expand the city's tram and bus network, create dedicated tram and bus lanes, give priority to transit vehicles over automobiles, and promote walkability within Zurich's core (Mees, 2010). The adoption of this plan resulted in rejecting a proposal to build three highways in the ZMA, marking a shift away from vehicle use toward mass transit (Mees, 2010). The People's Initiative for Public Transport 
led to the adoption of several new transit policy initiatives beginning in the 1980 s that define Zurich's transit system today.

\section{Current State of Zurich's Transit System}

With a mandate to improve its transit system, Zurich began adopting new transit policies that included reorganizing transit route stops, increasing accessibility (Nash, 2003), improving the road network to enable the efficient movement of transit vehicles and cars on roads, and to give transit vehicles a 5-8 second priority signal at traffic lights (Nash, 2003). Zurich continues to adopt a number of policies to create efficient, shared road space. They include dedicated public transit lanes, highway ramp metering on twenty roads entering the city, and roundabouts to keep traffic flowing (Furth, 2005). These reforms give priority to residents using transit, while also creating an efficient travel network for vehicles, leading to streets that pedestrians, transit users, and vehicle owners can share.

While the City of Zurich adopted transit priority reforms throughout the 1980s, the Canton of Zurich began investment in a regional transit network. The Zurich Canton invested in regional rail in the 1980s and integrated routes with local modes of transit. In 1990, a referendum approved the Zürcher Verkehsverbund (ZVV) (Mees, 2010), which is responsible for providing all features of Cantonal transit (Christodoulou and Finger, 2012; Buehler et al., 2019). The organization gains its revenue from fares and subsidies, while receiving funds from the Canton of Zurich and its respective municipalities (Mees, 2010). The Verkehsverbund is a transit model that combines suburban rail (S-Bahn) with subways (U-Bahn) to move people across both short and long distances. Zurich's tram network complements the suburban rail system, in place of a metro (Pucher \& Kurth, 1995). The Canton's bus system supports the movement of smaller 
crowds on local lines and helps feed passengers to larger transit lines. The connectivity of Zurich's transit system promotes walking and cycling by allowing residents to park bikes at transit stops (Buehler et al., 2019). The ZVV's fare structure also creates incentives for residents to use the transit system as an efficient way of getting around. All fares are integrated in a zonal system, making monthly or annual transit passes in Zurich more cost effective than single fare tickets (Pucher \& Kurth, 1995). As well, seniors, university students, and school students receive $52 \%$ to $95 \%$ discounts off a single fare. (Buehler et al., 2019). In so doing, Zurich's policy provides incentives for residents to use transit.

\section{VANCOUVER}

\section{City Profile}

Vancouver is western Canada's largest metropolis and Metro Vancouver is the region's largest metropolitan area. Metro Vancouver is the economic engine of British Columbia, and provides an important maritime connection to the pacific and western United States. Vancouver has a population of 603,000 within the City proper (City of Vancouver, 2016) while the Metro Vancouver area is home to approximately 2.4 million people. Metro Vancouver consists of 21 municipalities including an electoral area and Treaty First Nations (Metro Vancouver, n.d.a). Metro Vancouver maintains jurisdiction over several public services including water, wastewater, regional parks, housing, and select infrastructure and regional planning policies (Metro Vancouver, n.d.a); however, the lower-tier municipalities that constitute Metro Vancouver have additional political responsibilities (Hutton, 2011). In many respects, the city and its potential for development are constrained by its maritime borders. Vancouver is an 
important Canadian municipality and despite the challenges created by its natural boundaries, it has emerged as a liveable city with potential transit policies lessons for the GTHA.

\section{Vancouver's Transit System}

Residents in Metro Vancouver depended on automobiles from the 1950s until the mid-1970s. Not surprisingly, until 1980, transportation policies in Metro Vancouver focused on improving road conditions for cars (Meligrana, 1999; Stone, 2014). In 1972, The Electors Action Movement (TEAM), a pro-transit, municipal political party, won a majority on Vancouver City Council. TEAM shared a similar public transit ideology with members of the Council of the Greater Vancouver Regional District (GVRD), Metro Vancouver's upper tier of municipal government. The collaboration of TEAM and the GVRD led to the release of the 10-year plan GVRD Liveable Region Plan beginning in 1975 (Stone, 2014). This public policy was the region's first attempt to improve the existing transit infrastructure, including coordinating traffic signals, promoting carpooling, creating dedicated bus lanes, investing in bus rapid transit, lightrail transit, suburban rail, and ferries. While this plan did not displace cars, it did increase transit ridership and made the mid-1970s a transition point in Metro Vancouver's history as local politicians viewed transit as a viable solution to congestion in the region.

In the 1980s, Metro Vancouver continued its gradual steps toward improving transit. By 1983, the transit system was consolidated under provincial control through BC Transit (Meligrana, 1999). The opening of TransLink's Expo Line in 1985 was the first step toward creating a mass transit system in Vancouver, in large part to transport visitors to Expo 86, hosted in Vancouver. The idea was that Vancouver would show the world its innovative driverless, 
surface rail train (Stone, 2014). The construction of the first SkyTrain line and support for additional transit planning was critical to improving transit.

The defining moment of Vancouver's current transit system was the foundation of TransLink in 1998. Translink maintained control over the entire transit infrastructure built in Metro Vancouver, which at that point was limited to the Expo Line SkyTrain line, bus service, the West Coast Express regional railway service, and a ferry connecting Vancouver and North Vancouver. While under Translink, Metro Vancouver saw large investments in its transit system that define the system today, contributing to significant ridership gains over the last twenty years.

\section{Current State of Vancouver's Transit System}

As the backbone of Vancouver's transit system, the SkyTrain was expanded and complemented by other modes of transit. Today, the SkyTrain has three lines-- the Expo Line, Millennium Line, and Canada Line, completed for the 2010 Winter Olympics, and the recently opened the Evergreen extension to the Millennium Line, making it the longest rapid transit system in Canada (Singer \& Burda, 2014). The SkyTrain is supported by other rapid transit infrastructure, including an extensive bus system and regional rail. Vancouver's rapid bus service, the B-Line, moves passengers to stations along SkyTrain routes (Fischer \& Scheer, 2007). B-Line bus route stations are spaced roughly a kilometer apart; busses are larger; and, streets are designed to support the bus network (Translink, n.d.). The West Coast Express connects suburbs such as Mission City with Downtown Vancouver, and has eight regional rail stations, three of which connect with the Canada line ("West Coast Express Geographical Map," n.d.). The Seabus ferry and an extensive network of cycling and pedestrian routes augment these main forms of transportation. The Vancouver Greenway Network consists of 17 dedicated, recreational 
pathways for pedestrians and cyclists (City of Vancouver, 2013). In Metro Vancouver, bus, light rail, regional rail, and pedestrian/cycling networks merge to provide transit to the Metro Vancouver area, and connect passengers throughout the city.

\section{SEOUL}

\section{City Profile}

Seoul and its surrounding national capital region make up one of the largest cities and metropolitan areas in the world. Seoul has a population of 10 million people within $605 \mathrm{~km} 2$ of land. Seoul is denser than Beijing, Tokyo, London, and New York (SMG, 2016) and is defined by several geographical features including mountains and the Hangang River running through the city, which place limits on its development (SMG, n.d.; SMG, 2016).

\section{Seoul's Bus System Reform}

Seoul's transit system is defined by the intersection of bus, metro, and railway transit within the metropolis. In 2004, the Seoul Metropolitan Government (SMG), Seoul's municipal government, unveiled many policy initiatives to improve Seoul's bus service including increased control over operators, new funding structures, rerouting the bus network, a new fare structure, and investments in infrastructure (Pucher, Park, Kim, \& Song, 2005). The SMG expanded its power over bus operators, granting itself the ability to control all aspects of the system, leaving only the operation of the system to private companies (Pucher et al., 2005). A significant reform was the SMG expanding its control over operators and funding. The SMG replaced a funding system where operators received resources based on the number of passengers and distance travelled where longer routes receive more funding (Pucher et al., 2005). In addition, the bottom $50 \%$ of 
bus operators were to receive the same amount of funding - based on the average from the least profitable half of operating companies - as an incentive to ensure the top 50\% remained efficient. Similarly, only the top 70\% received generated profit (Kim, Cheon, and Lim, 2011). The reforms to the funding model promoted competition and enabled companies to improve service operations to make routes efficient and profitable, rather than focussing on squeezing as many passengers as possible on buses. Infrastructure improvements such as the construction of bus rapid transit routes, and dedicated curbside lanes (Kim et al., 2011) along with colour coding the bus network's 400 routes all helped to make transit work smoothly (Pucher et al., 2005). Supporting these reforms was the adoption of a distance-based fare with free transfers between buses and the metro using a smart card (Kim et al., 2011). Technological infrastructure was improved through the creation of a bus management system allowing buses to be monitored using GPS signals, enabling the SMG to allocate additional resources along bus routes, if necessary, while providing updates to passengers about performance (Pucher et al., 2005).

\section{HOW DO THESE TRANSIT SYSTEMS ENHANCE LIVEABILITY?}

Stepping back, how do the transit policies in these jurisdictions contribute specifically to liveability goals? While expanding transit in absolute terms does not necessarily make cities liveable, current urban trends have enhanced surface-level transit networks resulting in stabilizing or decreasing vehicle use, while encouraging walking and cycling (Biddulph, 2012; Hooper et al., 2015). In Zurich City, the vast majority of trips use public transit as opposed to cars (Mees, 2010). The number of Vancouverites using transit increased from $14.3 \%$ to $20.4 \%$ from 1996 to 2016 (Translink, 2017). Going forward, Vancouver's transit services will become increasingly vital as Metro Vancouver's 2040 goals indicate that the city will become denser, 
and rely on sustainable forms of transit to move people of all ages and incomes, with the added advantage of fighting climate change (Metro Vancouver, n.d.b). In Seoul, vehicle use has decreased modestly, while transit use has increased (Kim, Cheon \& Lim, 2011). Finally, Zurich and Vancouver have expanded pedestrian and cycling infrastructure, while Seoul has begun the process of creating streets that encourage walking and cycling.

The promotion of active modes of transportation in all three jurisdictions shows progress toward encouraging active living, a key component of liveable cities. As Johan Faskunger identifies through his survey research, the 77 cities around the world in the World Health Organization's European Healthy Cities Network (WHO-EHCN) all promote walking and cycling through networks of green paths, new trails, dedicated pedestrian spaces, cycling lanes, and sidewalks that are spacious and separated from roadways (2013). Zurich and Vancouver's transit policies encourage active living by adopting similar approaches for cyclists and pedestrians.

Liveability also promises to promote a strong economy. Today, cities are in constant competition for economic investment to bring high paying jobs to residents that will also enrich local communities. The global competition to host Amazon's HQ2 is a recent and notable example of the fierce competition among cities to attract investment. While businesses have many requirements when deciding where to invest, strong public transit is a critical factor. For HQ2, Amazon requested that host sites provide access to mass transit on-site, including bus, train, or subway routes; be within 45 minutes of a major international airport; and, be within 1.5$3.6 \mathrm{~km}$ of a major highway (Amazon.com Inc., 2017). When cities like Zurich, Vancouver, and Seoul improve their transit systems, they are not just improving connectivity, they may also be 
attracting investments and jobs. Investing in transit can have spin-off effects that improve the economic component of liveability.

Liveability also focuses on reducing pollution to protect the natural environment. One of the largest sources of urban pollution comes from transportation. For example, in cities in the top ten of both Mercer's and EIU rankings that are C40 members, (Tokyo, Seoul, Toronto, Auckland, Melbourne, Sydney, Vancouver and Copenhagen; Mercer, 2019; EIU, 2018), transportation accounts for an average of $27.9 \%$ of total GHG emissions (C40 Cities, 2014). The transportation sector, meaning both public and private transportation and the transportation of goods, represents an opportunity for cities to decrease carbon emissions and air pollution. By investing in transit, especially sustainable and electric forms of transit, cities can enhance liveability by decreasing car use, thereby reducing their overall GHG emissions. 


\section{CHAPTER 3: THE GTHA AND LIVEABLE TORONTO}

What are the policy applications for the Greater Toronto and Hamilton Area? The GTHA is the largest metropolitan region in Canada and a North American economic powerhouse. As of 2013, the GTHA was home to 6 million people, a number that is expected to increase to 8.6 million by 2031 (Metrolinx, 2008a). There are thirty municipalities in the GTHA, two are single-tier (Hamilton and Toronto), four are upper-tier regional governments (York, Peel, Durham, Halton), and twenty-four are local, lower-tier municipalities (Metrolinx, 2008a). The lower and upper-tier municipalities constitute the same geographical areas (see Figure 1) and they work closely together in conjunction with the Province of Ontario to provide services to the public. Toronto, as the largest city in the GTHA, is the only GTHA city discussed in liveability rankings. Although Toronto ranks high on several liveability indices, ranking sixteenth on Mercer's Quality of Living City Rankings and seventh on EIU's Global Liveability Index, it received its lowest score within the EIU Index under infrastructure (2019). In fact, Toronto had the lowest score in the infrastructure category of any city ranked in the top ten of the EIU's most recent ranking (2018). While Toronto has many features that make it liveable, it faces many transit challenges that potentially weaken its liveability for residents. 


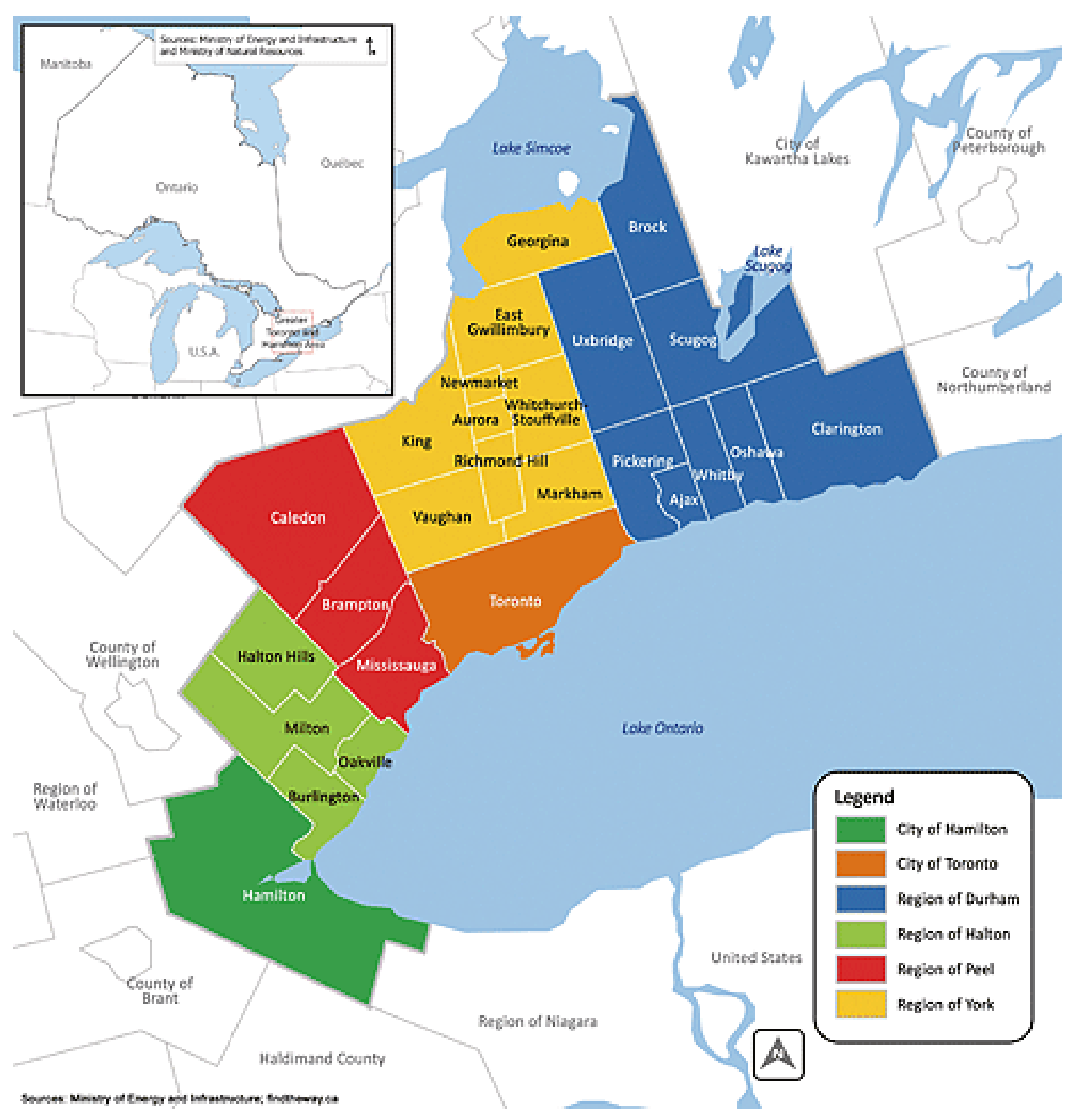

Figure 1 - GTHA upper and lower-tier municipalities (Metrolinx, 2008a, p. 4)

\section{OVERVIEW OF THE GTHA'S TRANSIT INFRASTRUCTURE}

The current GTHA transit system consists of a variety of provincial and municipal assets. The provincial transit infrastructure includes Ontario 400 series highways (400, 401, 403, 404, Queen Elizabeth Way and the privately owned 407) and GO Transit, a regional transit network that 
consists of 8 regional rail lines, and several bus routes that connect suburbia to the downtown core (Metrolinx, 2019a). Nine municipalities (Hamilton, Burlington, Milton, Oakville, Mississauga, Brampton, Toronto, York Region, and Durham Region) have their own transit systems. Many of these systems are small and only provide bus service (Metrolinx, 2015). The City of Toronto maintains two expressways, the Don Valley Parkway and the Gardiner Expressway, and the Toronto Transit Commission (TTC), which operates a four-line subway system, several streetcar routes, and many bus routes. While the GTHA does not have an extensive subway network, it does provide regional transit connectivity through various hubs. For example, GO Transit's rail lines begin and end at downtown Toronto's Union Station, the busiest station in the network ("Ridership Performance," 2018). Other transit hubs connecting local municipal service with the TTC include one GO Station, four TTC subway lines, Promenade Mall, and three university campuses. These hubs are located in Toronto's suburbs and neighboring communities such as Scarborough, North York, Etobicoke, Vaughan, Mississauga, and Brampton (Durham Region Transit, n.d.; Toronto Transit Commission, n.d.; York Region Transit, n.d.; Corporation of the City of Brampton, 2018; City of Mississauga, n.d.)

\section{ISSUES WITH THE GTHA'S TRANSIT SYSTEM}

\section{The City of Toronto's Inability to Build Transit Infrastructure}

In the last thirty years, the TTC's ability to build transit has stalled as various actors and orders of government debate the future of the transit system. Metrolinx, Ontario's regional transportation agency, founded in 2006 to coordinate, operate, and deliver several long-term transportation projects (Metrolinx, 2019b) has worked to build some of the most significant transit improvements in the GTHA's history. Projects include the controversial rollout of the 
PRESTO card and the construction of the Eglinton Crosstown to be completed in 2021

(Metrolinx, 2019b). The Big Move, Metrolinx’s first Regional Transportation Plan for the GTHA (2008a), supported the opening of two mass transit lines, the Union-Pearson Express in 2015, the extension of the TTC's York-University-Spadina subway to Vaughan in 2018 (Metrolinx, 2018), as well as the expansion of four GO Transit's regional railway lines. Other improvements include building three bus rapid transit (BRT) lines and expanding two-way GO Service and GO Bus service (Metrolinx, 2019b). Metrolinx, as a provincially governed regional transportation authority, has constructed much of the GTHA's new transit infrastructure. Nonetheless, the GTHA is still largely behind in building transit infrastructure, especially in the City of Toronto. Transit policy in the GTHA has been stymied by endless debates about the direction of transit where politics often takes priority over practicality.

\section{Fares}

Where there is access to transit in the GTHA, the lack of fare integration policies can pose a financial burden on people who must commute. All nine municipal transit agencies and GO Transit have their own fare structure. With the exception of Milton, all other municipal transit agencies have integrated fare agreements among themselves and with GO Transit (Metrolinx, 2015). However, the TTC does not maintain a fare integration agreement with any transit agency. As a result, when commuters from a GTHA transit system transfer to the TTC or vice versa, they must pay another agency's flat fare thus creating a "two-fare wall." This scenario can mean that transportation is a major expense for those who cross the boundaries of the GTHA's municipalities to get to and from their destination. It can also mean that driving to the city core is 
a viable financial option. Recall that Zurich, Seoul, and Vancouver resolved the multi-fare issue

by creating one transit agency for their entire metropolitan areas with an integrated fare structure.

\section{Costs of Congestion and Inadequate Transit}

A lack of integration among transit agencies in the GTHA may persuade residents to drive rather than to take transit, furthering the GTHA's road congestion. The underlying theme of a

Metrolinx 2008 report is that the most effective method to reduce congestion is to build regional transit infrastructure with connections proposed in the Big Move plan, suggesting that the GTHA's existing transit infrastructure is not sufficient to address congestion (Metrolinx, 2008b). The Metrolinx report outlined the consequences of congestion including its non-economic and economic costs to commuters. Metrolinx uses a common metric, the time travel index (TTI), to measure how much time is added on average to a commute, regardless of transit mode, in periods of high congestion. The TTI is expressed as a ratio of commute time in non-congested periods to commute times in periods of high congestion, such as rush hour. The average difference between these two periods is calculated for the same trip, to determine the ratio (Metrolinx, 2008b). Essentially, the TTI measures the additional time people spend commuting in rush hour as compared to the same trip outside of rush hour. Metrolinx notes that people often ignore the impact that driving, rather than taking transit, has on traffic. Since roads may not have the capacity to hold additional motorists, vehicle speeds on roads decrease during periods of congestion (Metrolinx, 2008b). Reduced speeds cause increases in TTI and commute times for motorists and as well as those who use surface-level public transit, since transit vehicles often get delayed in road traffic. The TTI was an average of 1.63 across the GTHA in 2006. Larger municipalities such as Toronto and Peel Region were above average with 1.75 and 1.88 
respectively (Metrolinx, 2008b). A high rate of TTI means that commutes in the GTHA in 2006 were on average $63 \%$ longer during rush hour than at non-peak hours, compelling commuters to spend more time on the road rather than on other activities. Sweet, Harrison, and Kanaroglou found that the TTI in the GTHA remains high, especially along highways 401, 400, and 404, where the TTI was a minimum of 1.12 during the morning commute, and 1.22 during the evening commute as of 2011 (2015). This rate of TTI indicates that commuters using these highways, which are vital arteries that link the GTHA's communities, have a commute at least 12 to $22 \%$ longer during rush hour versus non-rush hour periods. The historical and current high rates of TTI in the GTHA are concerning given that in 2011, Torontonians had the longest commute in Canada. A minimum of 11 minutes added to a Torontonian's average 66-minute roundtrip commute is the result of excess congestion that does not exist outside of rush hour (Higgins, Sweet, \& Kanaroglou, 2018). Furthermore, the City of Toronto found that Toronto's average office worker commutes 7 hours a week to get to and from work, the equivalent of a standard workday (2014). If the GTHA's transit networks were more effectively integrated among municipalities and within suburbs, commuters may be less likely to drive, thereby decreasing congestion and TTI. The high rates of congestion in the GTHA have spillover effects for the region's roads and residents. Additional traffic as a result of congestion ranges between $13.7 \%$ and $15.4 \%$ across the GTHA (Metrolinx, 2008b), adding to the pollution in the region, given that a third of the GTHA's carbon emissions come from transportation (The Atmospheric Fund, 2018, p. 13).

Congestion also has a significant impact on the economy. In 2006, congestion costs the average GTHA resident $\$ 552$ per year due to time delay, additional costs for vehicles, and emissions. The total annual cost to commuters was $\$ 3.3$ billion a year (Metrolinx, 2008b). 
Congestion not only increases the cost of living, it also harms the economy and discourages investment in the GTHA. The reduction in gross domestic product (GDP) associated with congestion was estimated to be $\$ 2.7$ billion a year as of 2006 , and lost business revenue was projected to be $\$ 4.7$ billion in the same year (Metrolinx, 2008b). Today, the numbers are much worse, showing the crippling effect that congestion has on the economy. In 2014, congestion cost the GTHA's economy more than $\$ 6$ billion a year (City of Toronto). This figure is nearly double Metrolinx's 2008 projected cost of congestion to the GTHA's, further demonstrating that congestion is a serious economic issue that needs attention. Congestion costs Ontarians economically, as companies seek to invest in cities with good transit systems.

The lack of an efficient transit system can also have negative social effects on specific populations in the GTHA. For example, StudentMoveTO's research on travel patterns of students commuting across the GTHA to the six university campuses (York University Keele \& Glendon campuses; University of Toronto St. George and Scarborough campuses, Ontario College of Arts and Design, and Ryerson University) found that 25\% of Toronto's postsecondary students live $20 \mathrm{~km}$ or more from campus (StudentMoveTO, 2016). In a survey of 12,600 university students, Coutts, Aird, Mitra, and Siemiatycki found that $33.4 \%$ of students have an hour-long commute, one way (2018). As a result, $63 \%$ of students were discouraged from travelling to campus because of the long travel time, $46 \%$ select courses based on commute times, and $65 \%$ responded that their commute made them less likely to participate extracurricular events on campus (2018). The unintended consequence may be to weaken social cohesion in the city among university students. 


\section{THE STATUS OF TRANSIT POLICY IN ONTARIO}

\section{Context for Transit Action}

On June 7th, 2018, Ontario elected Doug Ford and the Progressive Conservative Party to the Ontario Legislature with a commanding majority. The Premier has made significant transit announcements that have a direct impact on regional transit systems. Specifically, the Ford government announced a $\$ 28.5$ billion dollar proposal (Figure 2) to build new, but mostly continue existing transit projects in the GTHA that will result in six major investments, a number of which were already proposed by previous governments. The proposal includes the extension of the Eglinton West LRT to Pearson Airport; continued support for already proposed extension of the Yonge Subway to York Region on its eastern leg; a revival of the three-stop subway extension to Scarborough; the continued funding of both the Finch West and Hurontario LRT; and, a new light rail Ontario Line, which replaces the proposed downtown relief line. All projects are expected to be completed between 2029 and 2031 (McLaughlin \& Pelle, 2019; Draaisma \& Powers, 2019). This plan, if it comes to fruition, would expand transit to parts of the GTHA; however, it would do so with minimal cross-municipal transit connectivity. 


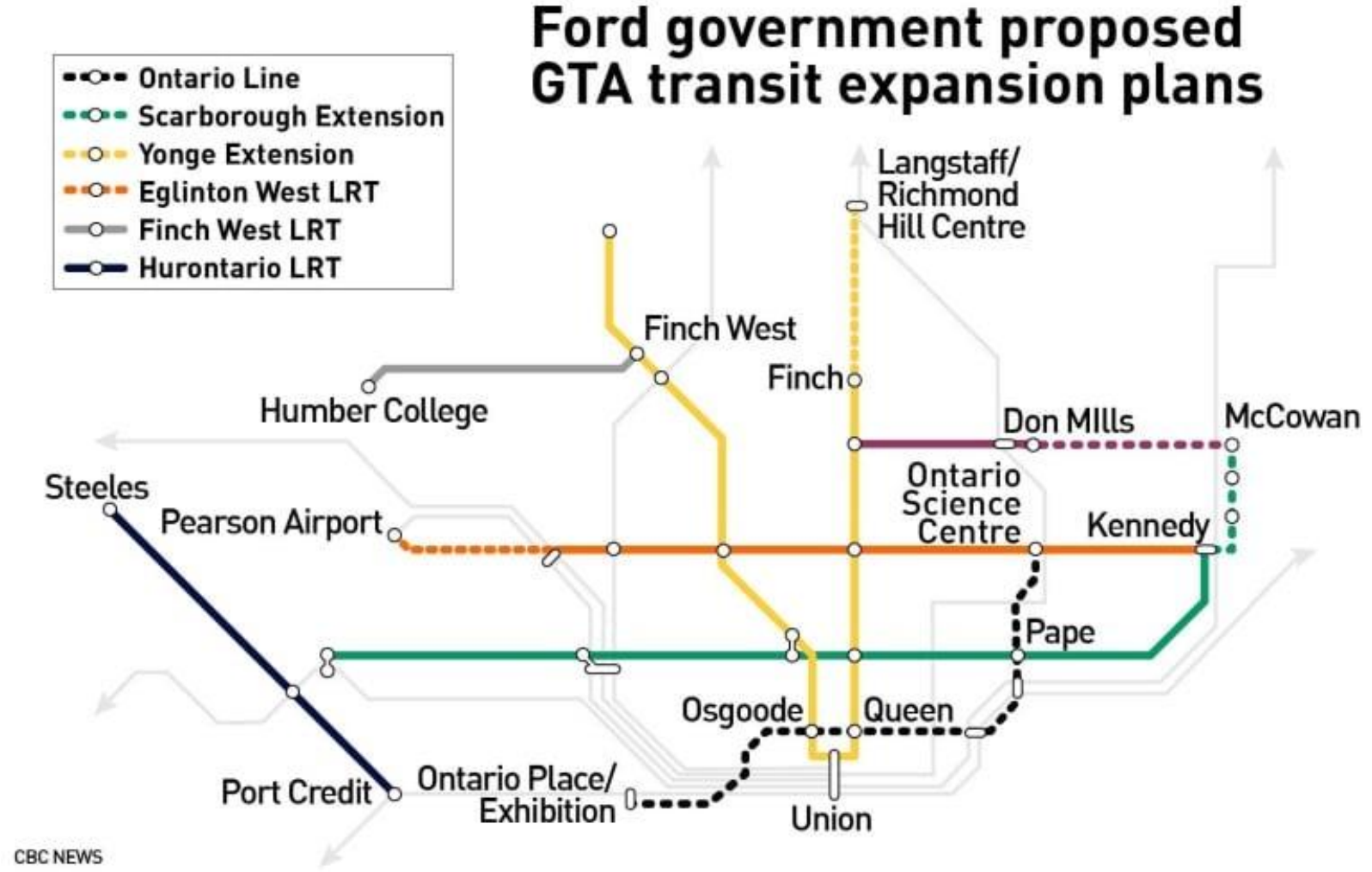

Figure 2 - Future Transit Expansion Proposals for the GTHA (Draaisma \& Powers, 2019)

Other transit policy changes made by the Ford government since taking office include uploading the TTC to the province, and cancelling the fare integration agreement between the TTC and GO Transit. On June 6th, 2019, the Getting Ontario Moving Act received Royal Assent, granting the province the ability to plan, develop, build, and own future subway lines (Spurr, 2019). The exact details of future provincial uploads have not been agreed upon and to a certain extent remain unknown. The other significant change is the cancellation of the discounteddoubled fare, which offers transit users transferring between GO Transit and TTC a $\$ 1.50$ discount per fare (CBC News, 2019). For reasons previously outlined, this action will have a negative impact on the affordability of public transit and on connecting and integrating transit seamlessly across systems.

To build transit infrastructure in the GTHA, numerous orders of government need to come together and provide funding. Currently, the provincial government's transit proposals 
have dominated transit policy discussions. The Ford government is seeking to secure the outstanding funds necessary to complete several transit projects, a total of \$17 billion (Draaisma $\&$ Powers, 2019). The federal government has to date ignored the new components of Ontario's transit plan, and has not provided any federal funding (Spurr, 2019). The City of Toronto continues to negotiate with the provincial government regarding the subway upload. Toronto City Council also voted to allow federal transit funds it has already received to be diverted to Premier Ford's proposals should all orders of government agree (CityNews, 2019; Moore, 2019). The other major government to benefit from the province's transit announcement is York Region. York Region and several of its local municipalities such as Markham, Richmond Hill, and Vaughan have welcomed the Premier's commitment to building the Yonge Subway North extension (Queen, 2019) and to the provincial subway upload.

\section{POLICY RECOMMENDATIONS FOR THE GTHA'S TRANSIT SYSTEMS}

Based on best practices from other jurisdictions, this MRP proposes several courses of actions that may enhance liveability through improving transit policies. If the GTHA continues on its current transit path, the GTHA could expect to see the opening of the Eglinton Crosstown LRT in 2021 (Metrolinx, n.d.a) and the construction of the Finch West LRT by 2023 (Metrolinx, n.d.b). Outside of Toronto, the Hurontario LRT is slated to be opened by 2022, (Metrolinx, n.d.c); the Hamilton LRT is expected to be completed in 2024 (Metrolinx, n.d.d); and, BRT networks will continue to be built throughout York Region and Mississauga (Metrolinx, n.d.e). While some transit expansion is occurring, none of these projects will improve transit across municipal boundaries within the GTHA, with the exception of the Hurontario LRT. Some of Toronto's highest priority transit projects, such as the downtown relief line, may not be 
completed until 2029 assuming a best-case scenario (Draaisma \& Powers, 2019). In the current state, major infrastructure projects for the City of Toronto are more than a decade away.

Transit fare integration, which proved effective in other jurisdictions, can be a policy option for the GTHA. Unfortunately, there is no discussion to date about integrating fares in the near future, and little will be done to coordinate the nine municipal transit agencies bus routes and stop times. These factors make transit inconvenient for users, potentially increasing car reliance and traffic congestion. If this is the case, Metrolinx's estimates that the cost of congestion to commuters could reach $\$ 7.8$ billion in Ontario by 2031 , and result in a $\$ 7.2$ billion reduction in the GTHA's GDP (Metrolinx, 2008b). This course of inaction may further weaken the economy and fuel the social costs of congestion. As previously discussed, multiple transit agencies making decisions around building transit has not led to effective transit planning.

\section{Surface Level Transit and Integration Upgrades}

A viable course of action would see transit agencies, with help from provincial and municipal governments, expand surface-level transit by continuing projects that have already proven successful. One example is the dedicated BRT routes throughout the GTHA. The Regional Municipality of York has emerged as a leader in BRT construction, as the Region has built and continues to build BRT along several of its arterial roadways including Highway 7 west and east, Yonge St, and Davis Drive. At a cost of \$261 million (Simon, 2015), York Region built a $2.7 \mathrm{~km}$ BRT with bike lanes along Davis Drive in Newmarket that was completed in three years (20122015). The project resulted in a $62 \%$ increase in ridership on the Viva Yellow bus route and a $33 \%$ reduction in route travel times since it opened (York Region Rapid Transit Corporation, 2017). Another dedicated rapid transit route, also proven successful, is Toronto’s King St. 
streetcar pilot project, now made permanent and dubbed the King St. Transitway, which limits cars on a portion of King St. in Toronto's downtown core to give priority to the TTC streetcar route on King. The King St. Transitway has increased all day weekly ridership by $17 \%$, improved route time performance by 5 minutes in both directions, and increased cycling on King St., while cars moved to nearby roads (City of Toronto, 2019). These benefits occurred at a cost of \$3 million (Ryerson City Building Institute, 2019). Building infrastructure improvements that enhance surface-level transit can result in dedicated transit routes that can be built within months to less than four years while improving ridership and decreasing traffic in cities.

\section{Superlinx}

Another policy option is Superlinx, which would represent a total reformation of the GTHA's transit system. Superlinx may be a credible alternative to the fragmented current state of GTHA transit. The Toronto Region Board of Trade (TRBT) published a report outlining the rationale behind Superlinx. Specifically, the report recommends the amalgamation of the nine GTHA transit agencies and an additional two from municipalities outside the GTHA, into a single provincial transit agency (Gill, Kelcey, and Parker, 2017). The governance structure of this agency could be similar to that of Metrolinx, and like Translink, include a board of directors that reports to municipal and provincial stakeholders. The creation of a single transit agency has several benefits. A single regional agency would facilitate planning and capital delivery by consolidating responsibilities in the provincial government, which has more powers than municipalities. It creates one network capable of route and fare integration; prioritizes building the highest priority infrastructure through a governance structure that would consolidate interests; and, creates a one-stop shop transit system for users with a common website, fare 
policy, and look (Gill et al., 2017). From a financial perspective, this plan ensures municipalities have a say in transit planning while removing transit-related operating, capital, and debt expenses from municipal budgets, although municipalities would still have to assist in subsidizing the operation of regional transit (Gill et al., 2017). This vision of regional transportation reflects the policies of several liveable cities including Zurich and Vancouver.

\section{Integrated Fares}

Regardless of whether Superlinx proceeds, a best practice policy option for the GTHA would be to integrate transit fares. The integration of fares would encourage transit use by making transit more affordable through the elimination of the two-fare wall system. There are many possible alternatives. For example, the GTHA could adopt a discounted double fare among its municipalities. Modifying the existing system to provide a discount of $50 \%$ to users transferring from one system to another would increase ridership $0.9 \%$ by 2031 and 905 -TTC ridership by 3.6\% (Metrolinx, 2016), and would cost approximately $\$ 137$ million in lost revenue among all agencies (Metrolinx, 2016). The GTHA municipalities and the province together could absorb the added cost. As the GTHA continues to build transit, fare integration will become increasingly necessary to promote affordability.

\section{Expand Walking and Cycling Paths across the GTHA}

In line with other liveable cities, another policy option is to expand the GTHA walking and cycling networks to promote active living and liveability. Adopting examples from Vancouver, transit planning could include bike lanes and wider sidewalks when creating new infrastructure such as BRTs and resurfacing roads. Projects to enhance cycling on city streets have been 
successful, as evidenced by the addition of bike lanes on a portion of Bloor St West in Toronto. This project resulted in a 49\% increase in cycling on the route from June 2016-2017, while vehicle use decreased, and 120 parking spaces were lost (City of Toronto, 2017a). Infrastructure planning might also consider enhancing the overall pedestrian and cycling network on a regional scale. The current cycling network (Figure 3) in Toronto excludes vast amounts of the city, especially its suburbs. The GTHA's municipalities and the province could continue adopting the proposed cycling network in the 2041 Regional Transportation Plan (Figure 4) (Metrolinx, 2018) in addition to expanding pedestrian and cycling networks locally.

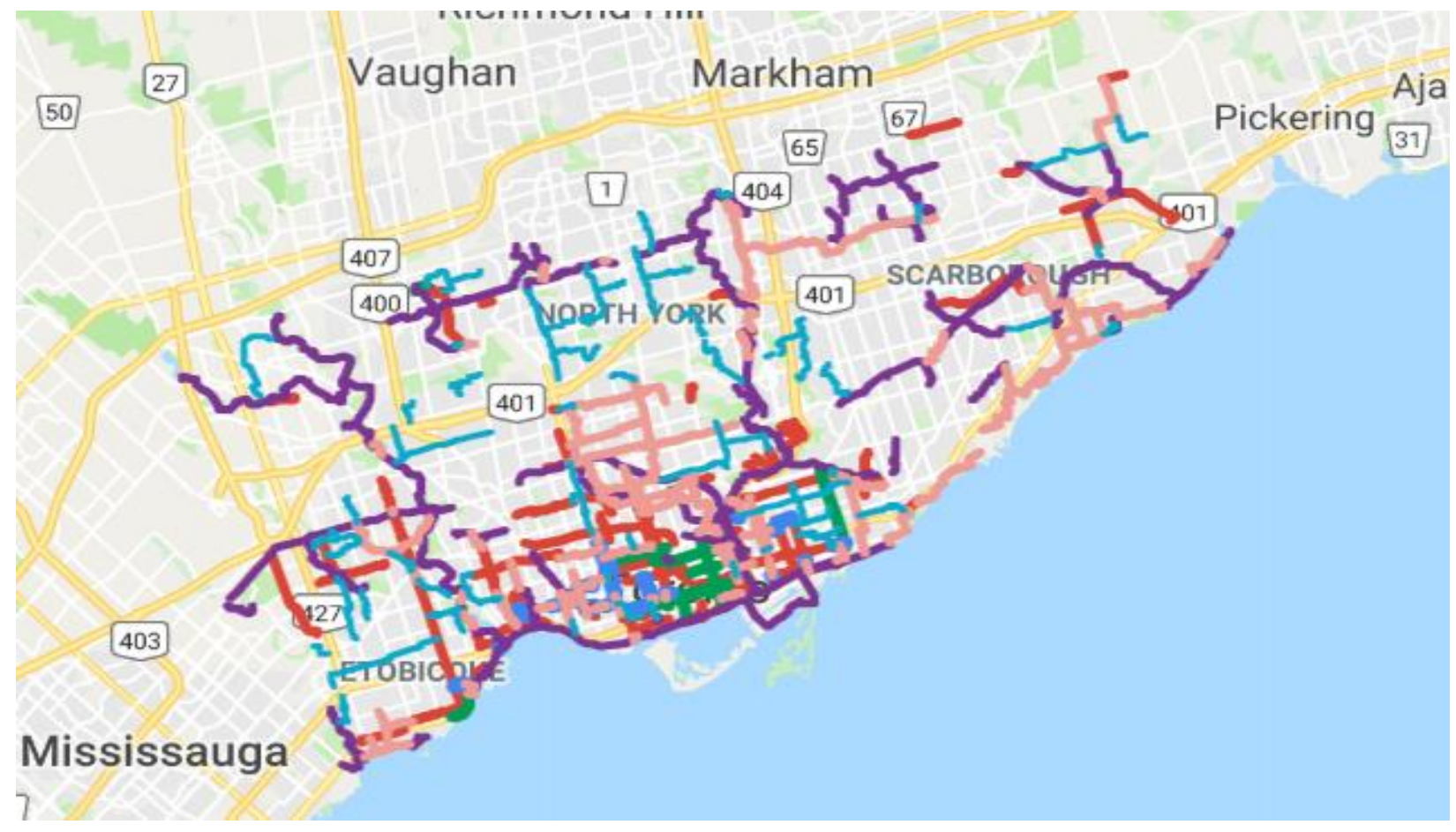

Figure 3 - Toronto's Current Cycling Network (City of Toronto, 2017b) 


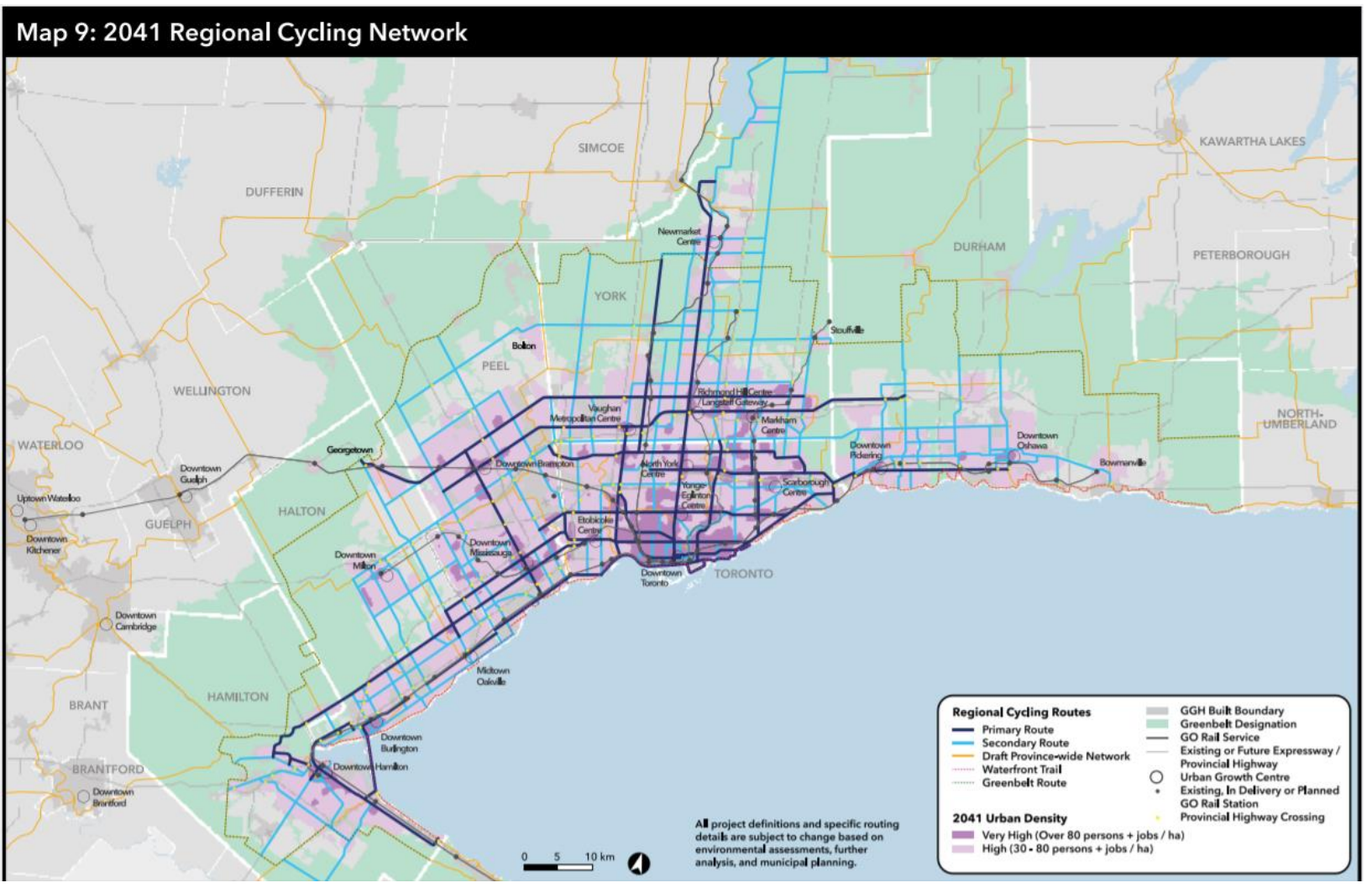

Figure 4 - Proposed GTHA Regional Cycling Network (Metrolinx, 2018, p. 97) 


\section{CONCLUSION: UNDERSTANDING TRANSIT THROUGH A LIVEABILITY LENS}

This MRP presented an overview of liveability indicators and asked whether transit policies can enhance liveability in urban centres. While various liveability indices tend to differ in detail, they generally present a common set of markers oriented toward promoting safe, clean, and vibrant cities for residents to achieve quality of life. A key challenge in examining the benefits of transit is that a good transit system alone does not make a city liveable, and hence, identifying the potential spin off effects was critical. Another challenge in studying the impact of transit is that liveability indicators often combined transit with other indicators such as infrastructure, the transportation of goods and public services, making it difficult to assess the contributions and benefits of transit alone (EIU, 2018; Mercer, 2019). However, as this MRP has attempted to show based on best practices found in the literature, and in its discussion of Zurich, Vancouver, and Seoul, having efficient public transit can enhance liveability by helping to promote the many ways in which residents can live vibrant and active urban lives. Efficient transit reduces congestion and smog thereby making the air cleaner and cities greener. Integrated transit networks encourage cities to build pathways for walking and cycling promoting healthier lifestyles, in line with the WHO recommendations (n.d.b). Well-functioning transit also connects people to essential public services, greenspaces, recreational and cultural activities, and the many other attractions in a city. With decreased congestion, transit can boost the economy by promoting the efficient transportation of goods. We noted that a strong public transit system may be a critical factor to attract global companies as decisions for economic investment and jobs may rest on access to efficient mass transit, including bus, train, or subway routes. Although studies have largely overlooked the importance of transit as a stand-alone factor, this MRP argues that a well-planned Thus, transit is key to improving multiple variables that enhance 
liveability. With the adoption of best practice transit policies, the GTHA can reduce its high rates of congestion both in the present and in the future. Promoting transit is critical because the GTHA faces a future of exponential economic and population growth. Transit holds the promise of promoting a more liveable, urban region. 


\section{APPENDICES}

Appendix 1 - EIU Liveability Rankings and Indicators

\begin{tabular}{|c|c|}
\hline Indlcator & Source \\
\hline Prevalence of perty crime & EIUrating \\
\hline Prevalence ofviolent coime & EIU rating \\
\hline Threat of terror & EUUrating \\
\hline Threat of milicary conflict & ElU rating \\
\hline Threat of chl unrestconflict & EIU rating \\
\hline
\end{tabular}

\section{Category 2: Healthcare (welght: $20 \%$ of total)} Indlcator

Source

Avallability of private healthere

EIUrating

Qually of private heathcare ElU rating

Avallabilly of publicheathcare ElU rating

Qualiy of publicheathcare ElUrating

Avallabllty of over-the counter drugs ElU rating

General heathcare Indicators Adapted from Worid Bank

\section{Category 3: Culture \& Environment (welght: $25 \%$ of total)}

Indlcawor

Humidty/temperature raing

Discomfort of clinate to trovellers

Level of corruption

Soctal or rellgous restrictions

Level of cersorstip

Sporing valablity

Culural avalablity

Food \& drink

Consumergoods \& services
Source

Adapted from 3 rerageweather condivons

EIU rating

Adapted from Transparency International

EIU rating

EIU rating

EIU fleid rating of 3 sport indlcators

EIU flaid rating of 4 cultural indlcators

EIU fleid rating of 4 cultural indlcators

ElU rating of product avalabilliy

\section{Category 4: Education (welght: 10\% of total)}

Indlcawor

Source

Avallabllity of private educcion

EIU rating

Qually of private educarion

EIUrating

Publiceducation ind cators

Adapted from World Bank 


\begin{tabular}{|c|c|}
\hline Category 5: Infrastructure & \\
\hline Indicator & Source \\
\hline Quallyy of rood neww ork & ElU rating \\
\hline Quallyy of pubicictransport & ElU rating \\
\hline Quality of international linis & ElU rating \\
\hline Avallabilly of good qualty housing & ElU rating \\
\hline Qualliy of energyprovision & ElU rating \\
\hline Quallyy of water provisson & ElU rating \\
\hline Qualliy of telecommunicarlons & ElU rating \\
\hline
\end{tabular}

Figure 5 - EIU Liveability Rankings and Indicators (EIU, 2018, pp. 8-9) 
Appendix 2 - Mercer Quality of Living Ranking, Indicator Categories

\section{QUALITY OF LIVING RANKING}

\section{What Factors Determine Quality of Living?}

These factors are evaluated in Mercer's Quality of Living Reports, which offer city-to-city comparisons for nearly 500 global assignment destinations.

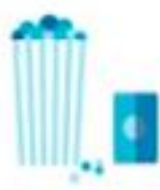

Recreation

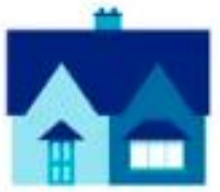

Housing

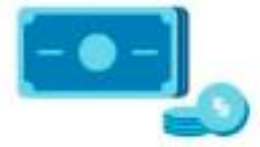

Economic environment

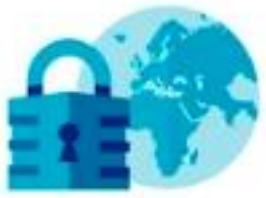

Political and social environment

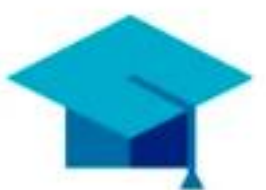

School and education

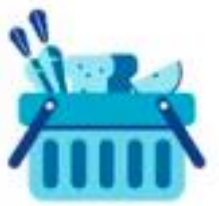

Consumer goods availability

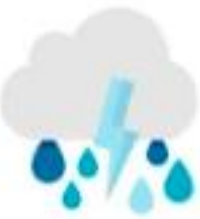

Natural environment

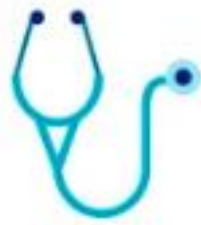

Medical and health considerations

Figure 6 - Mercer Quality of Living Ranking, Indicator Categories (Mercer, 2019) 
Appendix 3 - OECD BLI's Categories and Indicators

The following table shows the OECD BLI's categories and indicators in the order in which they are listed on the BLI's website:

\begin{tabular}{|c|c|}
\hline \multicolumn{2}{|c|}{ OECD BLI's Categories and Indicators } \\
\hline Category & Indicator \\
\hline \multirow[t]{3}{*}{ Housing } & Housing expenditure \\
\hline & Dwellings with basic facilities \\
\hline & Rooms per person \\
\hline \multirow[t]{2}{*}{ Income } & Household financial wealth \\
\hline & Household net adjusted disposable income \\
\hline \multirow[t]{4}{*}{ Jobs } & Job security \\
\hline & Personal earnings \\
\hline & Long-term unemployment rate \\
\hline & Employment rate \\
\hline Community & Quality of support network \\
\hline \multirow[t]{3}{*}{ Education } & Years in education \\
\hline & Student skills \\
\hline & Educational attainment \\
\hline \multirow[t]{2}{*}{ Environment } & Water quality \\
\hline & Air pollution \\
\hline \multirow[t]{2}{*}{ Civic engagement } & $\begin{array}{l}\text { Stakeholder engagement for developing } \\
\text { regulations }\end{array}$ \\
\hline & Voter turnout \\
\hline \multirow[t]{2}{*}{ Health } & Self-reported health \\
\hline & Life expectancy \\
\hline Life satisfaction & Life satisfaction \\
\hline \multirow[t]{2}{*}{ Safety } & Homicide rate \\
\hline & Feeling safe walking alone at night \\
\hline \multirow[t]{2}{*}{ Work-life balance } & Time devoted to leisure and personal care \\
\hline & Employees working very long hours \\
\hline
\end{tabular}

Table 1 - Adapted from OECD BLI (OECD BLI, n.d.a-k) 
Appendix 4 - European Green Capital Award's 12 Environmental Indicators

The selection of a city awarded with the title of European Green Capital is assessed on the basis of twelve environmental indicators:

- Climate Change: Mitigation

- Climate Change: Adaptation

- Sustainable Urban Mobility

- Sustainable Land Use

- Nature and Biodiversity

- Air Quality

- Noise

- Waste

- Water

- Green Growth and Eco-innovation

- Energy Performance

- Governance

Figure 7 - European Green Capital Award's 12 Environmental Indicators (European Green Capital Award, n.d.) 
Appendix 5 - Global City Indicators Program Categories and Indicators

\section{Table 1: City Services Themes}

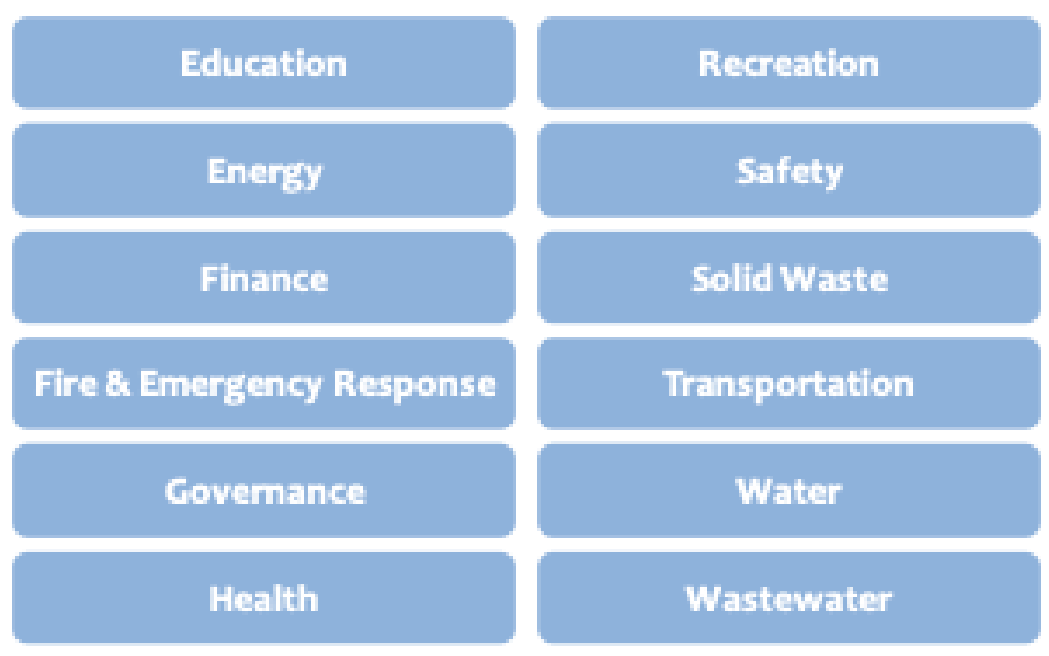

Table 2: Quality of Life Themes

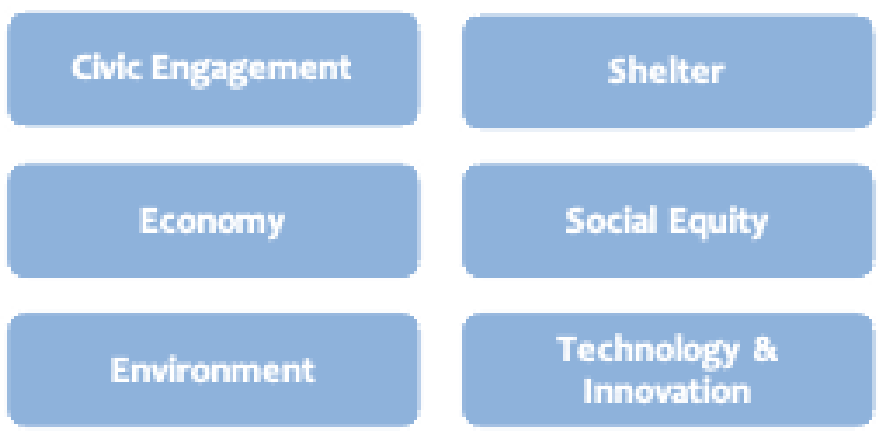

Figure 8 - Global City Indicators Program Categories and Indicators (Bhada \& Hoornweg, 2009, p. 3) 


\section{REFERENCE LIST}

Amar, A. K., \& Teelucksingh, C. (2015). Environmental justice, transit equity and the place for immigrants in Toronto. Canadian Journal of Urban Research, 24(2), 43-63.

Amazon.com, Inc. (2017, September 7). Amazon HQ2 RFP [Request for Proposal]. Retrieved from, https://images-na.ssl-imagesamazon.com/images/G/01/Anything/test/images/usa/RFP_3._V516043504_.pdf

Andersen, M., \& Reilly, S. (2016, February 23). Western European Cities top Quality of Living Ranking - Mercer. Retrieved from https:/www.mercer.com/newsroom/2016-quality-ofliving-survey.html

Andersen, M., Reilly, S., \& Siscovick, M. (2017, March 14). Vienna tops Mercer's 19th Quality of Living ranking. Retrieved from https://www.mercer.com/newsroom/2017-quality-ofliving-survey.html

Andersen, M., Tournier, C., \& Siscovick, M. (2018, March 20). Vienna tops Mercer's 20th Quality of Living ranking. Retrieved from https://www.mercer.com/newsroom/2018quality-of-living-survey.html

Badger, E. (2013, May 20). The Suburbanization of Poverty. Retrieved from https://www.citylab.com/life/2013/05/suburbanization-poverty/5633/

Badland, H., Davern, M., Villanueva, K., Mavoa, S., Milner, A., Roberts, R., \& Giles-Corti, B. (2016). Conceptualising and measuring spatial indicators of employment through a liveability lens. Social Indicators Research, 127(2), 565-576. doi:10.1007/s11205-0150978-6 
Balsas, C. J. (2004, February). Measuring the livability of an urban centre: An exploratory study of key performance indicators. Planning Practice and Research,19(1), 101-110. doi:10.1080/0269745042000246603

Bennardo, M. (2019, March 05). Time is money: Here's how your commute is costing you both. CBC News. Retrieved July 19, 2019, from https://www.cbc.ca/news/business/statisticscanada-commute-times-study-1.5038796

Bhada, P., \& Hoornweg, D. (2009). The Global City Indicators Program: A More Credible Voice for Cities. Directions in Urban Development. World Bank, Washington, DC. World Bank. Retrieved from, https://openknowledge-worldbankorg.ezproxy.lib.ryerson.ca/handle/10986/10244 License: CC BY 3.0 IGO.”

Biddulph, M. (2012). Radical streets? the impact of innovative street designs on liveability and activity in residential areas. URBAN DESIGN International, 17(3), 178-205. doi:10.1057/udi.2012.13

Buehler, R., Pucher, J., \& Dümmler, O. (2019). Verkehrsverbund: The evolution and spread of fully integrated regional public transport in Germany, Austria, and Switzerland. International Journal of Sustainable Transportation, 13(1), 36-50. doi:10.1080/15568318.2018.1431821

C40 Cities. (2014, December). [Interactive dashboard \& maps] Open Data-C40 Greenhouse Gas Protocol for Cities Interactive Dashboard. Retrieved July 21, 2019, from https://www.c40.org/research/open_data/5

CBC News. (2018, August 14). Calgary, Vancouver and Toronto ranked in top 10 of world's most livable cities. Retrieved June 27, 2019, from https://www.cbc.ca/news/business/canada-economist-liveability-1.4784524 
CBC News. (2019, July 9). Ford government to stop funding subsidy for discounted GTA transit fares. Retrieved August 11, 2019, from https://www.cbc.ca/news/canada/toronto/government-stop-funding-subsidy-discountedtoronto-transit-fares-1.5205707

Christoudoulou, A., \& Finger, M. (2012, May). The governance of urban public transport systems: the case of Zurich (ZVV). Network Regions and Cities in Times of Fragmentation, Delft University of Technology. Retrieved July 8, 2019, from https://3ftfah3bhjub3knerv1hneul-wpengine.netdna-ssl.com/wpcontent/uploads/2018/07/christodoulou-finger.pdf

City of Mississauga (n.d.). Maps. Retrieved August 11, 2019, from http://www.mississauga.ca/portal/miway/maps

City of Toronto. (2014). Deputy Mayor's Roundtable On Gridlock \& Traffic Congestion. Retrieved August 22, 2019, from https://www.toronto.ca/legdocs/mmis/2014/ex/bgrd/backgroundfile-72899.pdf

City of Toronto. (2015). Shaping the City. Toronto Official Plan - Chapter 2. Retrieved from https://www.toronto.ca/wp-content/uploads/2017/11/9048-cp-official-plan-chapter-2.pdf

City of Toronto, Transportation Services. (2017a, October 3). Bloor Street West Bike Lane Pilot Project Evaluation. Retrieved July 25, 2019, from https://www.toronto.ca/legdocs/mmis/2017/pw/bgrd/backgroundfile-107582.pdf

City of Toronto. (2017b, December 22). [Interactive map] Cycling Network Map. Retrieved July 25, 2019, from https://www.toronto.ca/services-payments/streets-parkingtransportation/cycling-in-toronto/cycling-google-map/ 
City of Toronto (2019). King Street Pilot: Annual Summary. Retrieved July 14, 2019, from https://www.toronto.ca/legdocs/mmis/2019/ex/bgrd/backgroundfile-131386.pdf

City of Vancouver. (2013, March 22). City greenways: Improving connections across

Vancouver. Retrieved July 12, 2019, from https://vancouver.ca/streetstransportation/city-greenways.aspx

City of Vancouver. (2016, August 30). Population. Retrieved July 12, 2019, from https://vancouver.ca/news-calendar/population.aspx

CityNews (2019, March 27). City council will continue subway upload talks after province lays out transit plans. Retrieved July 14, 2019, from https://toronto.citynews.ca/2019/03/27/ttc-upload-toronto-city-council/

Corporation of the City of Brampton (2018, September). [Network map] Brampton Transit Rider Guide. Retrieved August 11, 2019, from http://www.brampton.ca/EN/residents/transit/plan-yourtrip/PublishingImages/BRT7841109_RiderGuide_2018_WEB_Map.jpg

Coutts, S., Aird, B., Mitra, R., \& Siemiatycki, M. (2018). Does commute influence postsecondary students' social capital? A study of campus participation at four universities in toronto, canada. Journal of Transport Geography, 70, 172-181.

doi:10.1016/j.jtrangeo.2018.06.006

Daily Hive Toronto. (2018, August 14). Toronto ranked 7th most liveable city in the world. Retrieved June 27, 2019, from https://dailyhive.com/toronto/toronto-most-livable-cityworld-2018 
Diamond, J., \& Thompson, D. (2018, May 12). The true costs of suburban sprawl. The Globe and Mail. Retrieved July 19, 2019, from https://www.theglobeandmail.com/opinion/thetrue-costs-of-sprawl/article15218154/

Draaisma, M., \& Powers, L. (2019, April 10). What you need to know about Doug Ford's contentious plan for transit in the GTA. CBC News. Retrieved July 14, 2019, from https://www.cbc.ca/news/canada/toronto/doug-ford-toronto-transit-plan-1.5091916

Durham Region Transit. (n.d.). Connecting Transit. Retrieved August 11, 2019, from https://www.durhamregiontransit.com/en/routes-and-schedules/connectingtransit.aspx\#TTC

Economist Intelligence Unit. (2014, August). A Summary of the Liveability Ranking and Overview. Economist Intelligence Unit Limited. Retrieved from http://www.eiu.com/Handlers/WhitepaperHandler.ashx?fi=Liveability-rankingsPromotional-August-2014.pdf\&mode=wp\&campaignid=Liveability2014

Economist Intelligence Unit. (2015, August). A Summary of the Liveability Ranking and Overview. Economist Intelligence Unit Limited. Retrieved from http://www.eiu.com/Handlers/WhitepaperHandler.ashx?fi=Liveability-Ranking-Aug2015.pdf\&mode=wp\&campaignid=Liveability 2015

Economist Intelligence Unit. (2016, August). A Summary of the Liveability Ranking and Overview. Economist Intelligence Unit Limited. Retrieved from http://www.eiu.com/Handlers/WhitepaperHandler.ashx?fi=Liveability+Ranking+Summa ry+Report+-+August+2016.pdf\&mode=wp\&campaignid=Liveability 2016

Economist Intelligence Unit. (2017). The Global Liveability Index 2017. Economist Intelligence Unit Limited. Retrieved from 
http://www.eiu.com/Handlers/WhitepaperHandler.ashx?fi=Liveability-Ranking-FreeSummary-Report-August-2017.pdf\&mode=wp\&campaignid=Liveability 17

Economist Intelligence Unit. (2018). The Global Liveability Index. Economist Intelligence Unit

Limited. Retrieved from https://pages.eiu.com/rs/753-RIQ-

438/images/The_Global_Liveability_Index_2018.pdf

European Green Capital Award. (n.d.). Evaluation Process. Retrieved July 19, 2019, from http://ec.europa.eu/environment/europeangreencapital/applying-for-the-award/evaluationprocess/

Faskunger, J. (2013). Promoting active living in healthy cities of Europe. Journal of Urban Health, 90(S1), 142-153. doi:10.1007/s11524-011-9645-7

Ferbrache, F., \& Knowles, R. D. (2017). City boosterism and place-making with light rail transit: A critical review of light rail impacts on city image and quality. Geoforum, 80, 103-113. doi:10.1016/j.geoforum.2017.01.013

Fischer, I., \& Scherr, W. (2007). Optimizing Transit Operations in Vancouver, B.C.: TransLink's Rapid Transit Model. 11th TRB Transportation Applications Conference. Retrieved July 12,2019 , from http://citeseerx.ist.psu.edu/viewdoc/download?doi=10.1.1.682.2715\&rep=rep1\&type=pdf

Furth, P. G. (2005, July 19). Public Transport Priority for Brussels: Lessons from Zurich, Eindhoven, and Dublin. Research in Brussels. Retrieved July 8, 2019, from http://www 1.coe.neu.edu/ pfurth/Furth\%20papers/2005\%20Prioity\%20Lessons\%20Zuri ch,\%20Brussels.pdf

Geller, A. L. (2003). Smart growth: A prescription for livable cities. American Journal of Public Health, 93(9), 1410-1415. doi:10.2105/AJPH.93.9.1410 
Gill, P., Kelcey, B., \& Parker, J. (2017, November 23). Superlinx: An uploading strategy for a modern provinical transit authority. The Toronto Region Board of Trade. Retrieved July 14, 2019, from https://www.bot.com/Portals/0/Board of Trade Metrolinx Submission_Superlinx Strategy_Nov2017.pdf

Higgins, C. D., Sweet, M. N., \& Kanaroglou, P. S. (2018). All minutes are not equal: Travel time and the effects of congestion on commute satisfaction in canadian cities.Transportation, 45(5), 1249-1268. doi:10.1007/s11116-017-9766-2

Hodges, T. (2010, January). Public Transportation's Role in Responding to Climate Change. United States of America, U.S Department of Transportation, Federal Transit Administration. Retrieved from https://www.transit.dot.gov/sites/fta.dot.gov/files/docs/PublicTransportationsRoleInResp ondingToClimateChange2010.pdf

Holden, M., \& Scerri, A. (2013). More than this: Liveable Melbourne meets liveable Vancouver. Cities, 31, 444-453. doi:10.1016/j.cities.2012.07.013

Hooper, P., Knuiman, M., Foster, S., \& Giles-Corti, B. (2015). The building blocks of a 'Liveable neighbourhood': Identifying the key performance indicators for walking of an operational planning policy in Perth, Western Australia. Health and Place, 36, 173-183. doi:10.1016/j.healthplace.2015.10.005

Hulchanski, D. (2007, December). The Three Cities within Toronto. Retrieved July 19, 2019, from http://www.urbancentre.utoronto.ca/pdfs/curp/tnrn/Three-Cities-Within-Toronto2010-Final.pdf 
Hutton, T. A. (2011). Thinking metropolis: From the 'livable region' to the 'sustainable metropolis' in Vancouver. International Planning Studies, 16(3), 237-255. doi:10.1080/13563475.2011.591144

International Organisation for Standardization (n.d.) GCIF - Global City Indicators Facility. Retrieved August 9, 2019, from https://www.iso.org/organization/660833.html

Kashef, M. (2016). Urban livability across disciplinary and professional boundaries. Frontiers of Architectural Research, 5(2), 239-253. doi:10.1016/j.foar.2016.03.003

Kenworthy, J. R. (2006). The eco-city: Ten key transport and planning dimensions for sustainable city development. Environment \& Urbanization, 18(1), 67-85. doi:10.1177/0956247806063947

Kim, K. S., Cheon, S., \& Lim, S. (2011). Performance assessment of bus transport reform in seoul. Transportation, 38(5), 719-735. doi:10.1007/s11116-011-9330-4

Krawchenko, T. (2011). Regional special purpose bodies for transportation and transit in canada: Case studies of Translink and Metrolinx. The Canadian Journal of Regional Science, 34(1), 1.

Leach, J. M., Lee, S. E., Hunt, D. V. L., \& Rogers, C. D. F. (2017). Improving city-scale measures of livable sustainability: A study of urban measurement and assessment through application to the City of Birmingham, UK. Cities, 71, 80-87.

doi:10.1016/j.cities.2017.06.016

Leyden, K. M., Goldberg, A., \& Duval, R. D. (2011). The built environment, maintenance of the public sphere and connections to others and to place: An examination of 10 international cities. Journal of Urbanism: International Research on Placemaking and Urban Sustainability, 4(1), 25-38. doi:10.1080/17549175.2011.559946 
Lowe, M., Whitzman, C., Badland, H., Davern, M., Aye, L., Hes, D., . . Giles-Corti, B. (2015). Planning healthy, liveable and sustainable cities: How can indicators inform policy? Urban Policy and Research, 33(2), 131-144. doi:10.1080/08111146.2014.1002606

Marshall, W. E., \& McAndrews, C. (2017). Understanding livable streets in the context of the arterials that surround them. Transportation Research Record, 2605(1), 1-17. doi:10.3141/2605-01

McArthur, J., \& Robin, E. (2019). Victims of their own (definition of) success: Urban discourse and expert knowledge production in the liveable city. Urban Studies, 56(9), 1711-1728. doi:10.1177/0042098018804759

McLaughlin, A., \& Pelley, L. (2019, April 10). Doug Ford commits \$11.2B for 4 major Toronto-area transit projects. CBC News. Retrieved July 14, 2019, from https://www.cbc.ca/news/canada/toronto/doug-ford-toronto-subway-upload-gta-transitplan-1.5090394

Mees, P. (2010). Transport for suburbia: Beyond the automobile age. London: Earthscan.

Meligrana, J. F. (1999). Toward regional transportation governance: A case study of greater Vancouver. Transportation, 26(4), 359-398. doi:10.1023/A:1005231322989

Mercer. (2019). Quality of Living City Ranking. Retrieved June 26, 2019, from, https://mobilityexchange.mercer.com/Insights/quality-of-living-rankings.

Metro Vancouver. (n.d.a). About Us. Retrieved from http://www.metrovancouver.org/about/Pages/default.aspx 
Metro Vancouver. (n.d.b). Metro 2040 Goals. Retrieved from

http://www.metrovancouver.org/services/regional-planning/metro-vancouver2040/goals/Pages/default.aspx

Metrolinx. (2008a, November). The Big Move: Transforming Transportation in the Greater Toronto and Hamilton Area. Retrieved from, http://www.metrolinx.com/thebigmove/Docs/big_move/TheBigMove_020109.pdf

Metrolinx. (2008b, December). Costs of Congestion in the GTHA: Impact and Cost Benefit Analysis of the Metrolinx Draft Regional Transportation Plan. HDR Corporation Decision Economics. Retrieved from, http://www.metrolinx.com/en/regionalplanning/costsofcongestion/ISP_08015_Cost_of_Congestion_report_1128081.pdf

Metrolinx (2015, September 24). Transit Fares in the GTHA Today - An Overview. Retrieved from Www.metrolinx.com/en/regionalplanning/fareintegration/Transit_Fares_in_the_GTHA_T oday-An_Overview_EN.pdf.

Metrolinx (2016, June). GTHA Fare Integration Backgrounder. Steer Davies Gleave. Retrieved from http://www.metrolinx.com/en/regionalplanning/fareintegration/GTHA_Fare_IntegrationConcept_Evaluation_Backgrounder_EN.pdf

Metrolinx. (2018). 2041 Regional Transportation Plan. Retrieved from http://www.metrolinx.com/en/regionalplanning/rtp/Metrolinx - 2041 Regional Transportation Plan - Final.pdf 
Metrolinx. (2019a, January). [Route Maps]. GO System Map. Retrieved August 11, 2019, from https://www.gotransit.com/static_files/gotransit/assets/pdf/TripPlanning/SystemMaps/20 1901-system-map.pdf.pdf

Metrolinx. (2019b). Metrolinx Overview. Retrieved from http://www.metrolinx.com/en/aboutus/metrolinxoverview/metrolinx_overview.aspx

Metrolinx. (n.d.a). Eglinton Crosstown LRT. Retrieved July 14, 2019, from http://www.metrolinx.com/en/greaterregion/projects/crosstown.aspx

Metrolinx. (n.d.b). Finch West LRT. Retrieved July 14, 2019, from http://www.metrolinx.com/en/greaterregion/projects/finchwest-lrt.aspx

Metrolinx. (n.d.c). Hurontario LRT. Retrieved July 14, 2019, from http://www.metrolinx.com/en/greaterregion/projects/hurontario-lrt.aspx

Metrolinx. (n.d.d). Hamilton LRT. Retrieved July 14, 2019, from http://www.metrolinx.com/en/greaterregion/projects/hamilton-lrt.aspx

Metrolinx. (n.d.e). Transit Expansion Projects. Retrieved July 14, 2019, from http://www.metrolinx.com/en/greaterregion/projects/transit-expansion-projects.aspx

Moore, O. (2019, April 17). Toronto City Council opens door to supporting Doug Ford's transit plan, with conditions. The Globe and Mail. Retrieved July 14, 2019, from https://www.theglobeandmail.com/canada/toronto/article-toronto-city-council-opensdoor-to-supporting-doug-fords-transit-plan/

Nairn, H. (2015, March 4). Canadian cities, led by Vacnouver, top North America Quality of Living Rankings - Mercer. Retrieved from https://www.mercer.ca/en/newsroom/2015quality-of-living-survey-canada.html 
Nash, A. (2003). Implementing Zurich's transit priority program. Transportation Research Record: Journal of the Transportation Research Board, 1835(1), 59-65. doi:10.3141/1835-08

Natural Resources Canada. (2016, September 20). Emission Impacts Resulting from Vehicle Idling. Retrieved July 27, 2019, from https://www.nrcan.gc.ca/energy/efficiency/communitiesinfrastructure/transportation/cars-light-trucks/idling/4415

Nofre, J., Giordano, E., Eldridge, A., Martins, J. C., \& Sequera, J. (2018). Tourism, nightlife and planning: Challenges and opportunities for community liveability in la barceloneta. Tourism Geographies, 20(3), 377-396. doi:10.1080/14616688.2017.1375972

O'Neil, L. (2019, March 20). Toronto ranked 16th most livable city in the world. BlogTO. Retrieved June 27, 2019, from https://www.blogto.com/city/2018/03/toronto-ranked-16most-livable-city-world/

Okulicz-Kozaryn, A. (2013). City life: Rankings (livability) versus perceptions (satisfaction).Social Indicators Research, 110(2), 433-451. doi:10.1007/s11205-0119939-x

Organization for Economic Co-Operation and Development Better Life Index. (n.d.a) How's Life?. Retrieved June 26, 2019, from http://www.oecdbetterlifeindex.org/\#/11111111111 Organization for Economic Co-Operation and Development Better Life Index. (n.d.b). Safety. Retrieved June 26, 2019, from http://www.oecdbetterlifeindex.org/topics/safety/ Organization for Economic Co-Operation and Development Better Life Index. (n.d.c) Health. Retrieved June 26, 2019, from http://www.oecdbetterlifeindex.org/topics/health/ 
Organization for Economic Co-Operation and Development Better Life Index. (n.d.d).

Education. Retrieved June 26, 2019, from

http://www.oecdbetterlifeindex.org/topics/education/.

Organization for Economic Co-Operation and Development Better Life Index. (n.d.e) Income.

Retrieved June, 26 2019, from http://www.oecdbetterlifeindex.org/topics/income/

Organization for Economic Co-Operation and Development Better Life Index. (n.d.f) Jobs.

Retrieved June, 26 2019. http://www.oecdbetterlifeindex.org/topics/jobs/

Organization for Economic Co-Operation and Development Better Life Index. (n.d.g) Housing.

Retrieved June 26, 2019, from http://www.oecdbetterlifeindex.org/topics/housing/

Organization for Economic Co-Operation and Development Better Life Index. (n.d.h)

Environment. Retrieved June 26, 2019, from

http://www.oecdbetterlifeindex.org/topics/environment/.

Organization for Economic Co-Operation and Development Better Life Index. (n.d.i) Work-Life

Balance. Retrieved June 26, 2019, from http://www.oecdbetterlifeindex.org/topics/worklife-balance/

Organization for Economic Co-Operation and Development Better Life Index. (n.d.j)

Community. Retrieved July 20, 2019, from,

http://www.oecdbetterlifeindex.org/topics/community/

Organization for Economic Co-Operation and Development Better Life Index. (n.d.k) Civic

Engagement. Retrieved July 20, 2019, from,

http://www.oecdbetterlifeindex.org/topics/civic-engagement/ 
Pucher, J., \& Kurth, S. (1995). Verkehrsverbund: The success of regional public transport in Germany, Austria and Switzerland. Transport Policy, 2(4), 279-291. doi:10.1016/0967070X(95)00022-I

Pucher, J., Park, H., Kim, M., \& Song, J. (2005). Public Transport Reforms in Seoul: Innovations Motivated by Funding Crisis. Journal of Public Transportation,8(5), 41-62. doi:10.5038/2375-0901.8.5.3

Queen, L. (2019, April 11). York Region 'applauds' announcement of Yonge North subway extension. Retrieved July 14, 2019, from https://www.thestar.com/news/gta/2019/04/11/york-region-applauds-announcement-ofyonge-north-subway-extension.html

Reiner, M., \& Rouse, D. (2018). Dependency model: Reliable infrastructure and the resilient, sustainable, and livable city. Sustainable and Resilient Infrastructure, 3(3), 103-108. doi:10.1080/23789689.2017.1386041

Ridership Performance Year to Date (YTD) (2018, April). [Map]. Ridership performance year to date (YTD) GO Train and UP Express April 2018 to November 2018. Retrieved July 14, 2019, from https://metrolinx.files.wordpress.com/2019/01/click-right-here-for-ourridership-map.pdf

Ruggeri, D., Harvey, C., \& Bosselmann, P. (2018). Perceiving the livable city: Cross-cultural lessons on virtual and field experiences of urban environments. Journal of the American Planning Association, 84(3-4), 250-262. doi:10.1080/01944363.2018.1524717

Ryerson City Building Institute. (2019, May 15). King Street by the Numbers. Retrieved July 14, 2019, from https://www.citybuildinginstitute.ca/2019/04/03/king-street-by-the-numbers/ 
Säumel, I., Weber, F., \& Kowarik, I. (2016). Toward livable and healthy urban streets: Roadside vegetation provides ecosystem services where people live and move. Environmental Science and Policy, 62, 24-33. doi:10.1016/j.envsci.2015.11.012

Seoul Metropolitan Government, Advisory Group for Urban Planning, Urban Planning Bureau. (2016, April). Seoul Urban Planning. Retrieved from https://www.metropolis.org/sites/default/files/seoul_urban_planningenglish.pdf

Seoul Metropolitan Government. (n.d.). City Competitiveness Index. Retrieved July 20, 2019, from http://english.kompass.kr/get-to-know-us/the-ranking-of-seoul/citycompetitiveness-index/5-gci-kearney-foreign-policy/

Seoul Metropolitan Government. (n.d.). Seoul location information - Where is Seoul? Retrieved July 12, 2019, from http://english.seoul.go.kr/get-to-know-us/seoul-views/meaning-ofseoul/2-location/

Simon, C. (2015, April 16). Newmarket's Davis Drive project expected to continue into 2016. York Region.com. Retrieved from https://www.yorkregion.com/news-story/5560991newmarket-s-davis-drive-project-expected-to-continue-into-2016/

Singer, G., \& Burda, C. (2014, September 5). Fast Cities: A comparison of rapid transit in major Canadian cities. Pembina Institute. Retrieved July 12, 2019, from https://www.pembina.org/reports/fast-cities-report.pdf

Siscovick, M. (2014, February 19). 2014 Quality of Living Worldwide Rankings - Mercer Survey - Mercer. Retrieved from https://www.uk.mercer.com/newsroom/2014-qualityof-living-survey.html

Smets, P. (2006). Living apart or together? multiculturalism at a neighbourhood level. Community Development Journal, 41(3), 293-306. 
Spurr, B. (2019, June 03). Province says it wants federal money for the Ontario Line. Ottawa says it needs more answers. Toronto Star. Retrieved July 14, 2019, from https://www.thestar.com/news/gta/2019/06/03/province-says-it-wants-federal-money-forthe-ontario-line-ottawa-says-it-needs-more-answers.html

Stadt Zurich. (2013, September 02). Facts \& Figures. Retrieved July 8, 2019, from https://www.stadtzuerich.ch/portal/en/index/portraet_der_stadt_zuerich/zahlen_u_fakten.html

Statistics Canada. (2019, February 25). Study: Long Commutes to Work by Car. Retrieved from https://www150.statcan.gc.ca/n1/daily-quotidien/190225/dq190225a-eng.htm

Stone, J. (2008). Political factors in the rebuilding of mass transit: An investigation of failure in Melbourne since 1970 through comparisons with Perth and Vancouver. Retrieved July 14,2019 , from https://pdfs.semanticscholar.org/ac94/be0e8e5f152221c87714d7aa94d42fc6ed0d.pdf

Stone, J. (2014). Continuity and change in urban transport policy: Politics, institutions and actors in Melbourne and Vancouver since 1970. Planning Practice and Research, 29(4), 388404. doi:10.1080/02697459.2013.820041

StudentMoveTO (2016, March) An Overview of Early Findings. Retrieved from, www.studentmoveto.ca/wpcontent/uploads/2018/06/StudentMoveTO.Handout_4Uni.v1.pdf.

Sweet, M. N., Harrison, C. J., \& Kanaroglou, P. S. (2015). Gridlock in the greater toronto area: Its geography and intensity during key periods. Applied Geography, 58, 167-178. doi:10.1016/j.apgeog.2015.01.011 
Swissinfo.ch. (2018, August 13). Zurich and Geneva ranked in top five most liveable cities in Europe. Retrieved July 20, 2019, from https://www.swissinfo.ch/eng/living-the-goodlife_zurich-and-geneva-among-top-five-european-cities/44319586

Tapsuwan, S., Mathot, C., Walker, I., \& Barnett, G. (2018). Preferences for sustainable, liveable and resilient neighbourhoods and homes: A case of Canberra, Australia. Sustainable Cities and Society, 37, 133-145. doi:10.1016/j.scs.2017.10.034

The Atmospheric Fund. (2018, July). Keeping Track: 2015 Carbon Emissions in the Greater Toronto and Hamilton Area. Retrieved July 25, 2019, from http://taf.ca/wpcontent/uploads/2018/09/TAF_Emissions-Inventory-Report_2018.pdf

Toronto Transit Commission (2018, October). [Interactive map] System Map. Retrieved August 11, 2019, from, https://www.ttc.ca/Subway/interactive_map/interactive_map.jsp\#

Translink. (n.d.). B-Line Program. Retrieved July 12, 2019, from https://www.translink.ca/Plansand-Projects/B-Line-Consultation.aspx

Tschopp, M., \& Axhausen, K. W. (2008). Transport infrastructure and regional development in Switzerland: Accessibility, spatial policy and urban sprawl during the last fifty years. The Journal of Transport History, 29(1), 83-97. doi:10.7227/TJTH.29.1.7

UN Habitat. (n.d.) Climate Change. Retrieved July 19, 2019, from https://unhabitat.org/urbanthemes/climate-change/

United Nations (n.d.) World Urbanization Prospects: The 2018 Revision. Retrieved from https://population.un.org/wup/Publications/Files/WUP2018-KeyFacts.pdf

United Nations Environment Program. (n.d.). Cities and climate change. Retrieved from https://www.unenvironment.org/explore-topics/resource-efficiency/what-wedo/cities/cities-and-climate-change 
Vilet, W. V. (2008, November 6). Creating Livable Cities for All Ages: Intergenerational Strategies and Initiatives. UN Habitat. Retrieved from http://mirror.unhabitat.org/downloads/docs/6264_30721_CreatingLivableCitiesforAllAge s.pdf

West Coast Express Geographical Map (2016, July 28). [Map]. Retrieved July 12, 2019, from https://www.translink.ca//media/Documents/schedules_and_maps/transit_system_maps/wce_network_map.pdf?la $=$ en $\&$ hash=28D61FADA884F6A32CC32FBB91C90AF06F382D25

World Health Organization. (n.d.a). Air Pollution. Retrieved July 19, 2019, from https://www.who.int/sustainable-development/cities/health-risks/air-pollution/en/

World Health Organization. (n.d.b). Healthy Settings. Retrieved August 25, 2019, from https://www.who.int/healthy_settings/types/cities/en/

York Region Rapid Transit Corporation. (n.d.). York Region Rapid Transit Corporation: Annual Report 2017. Retrieved from http://www.vivanext.com/PDFs/Corp/2017_Report_Annual_Web.pdf

York Region Transit (n.d.). System Maps. Retrieved August 11, 2019, from https://www.yrt.ca/en/schedules-and-maps/maps.aspx 